\title{
Evidence on the impact of minimum wage laws in an informal sector: Domestic workers in South Africa*
}

\author{
Taryn Dinkelman and Vimal Ranchhod
}

July 2010

What happens when a previously uncovered labor market is regulated? We exploit the introduction of a minimum wage in South Africa and variation in the intensity of this law to identify increases in wages and formal contract coverage, and no significant effects on employment on the intensive or extensive margins for domestic workers. These large, partial responses to the law are somewhat surprising, given the lack of monitoring and enforcement in this informal sector. We interpret these changes as evidence that external sanctions are not necessary for new labor legislation to have a significant impact on informal sectors of developing countries, at least in the short-run. [107 words]

Keywords: Minimum wage, informal sector, Africa

\footnotetext{
*tdinkelm@princeton.edu, vimal.ranchhod@gmail.com. Dinkelman is at Princeton University. Ranchhod is a senior lecturer at the University of Cape Town. Without implicating them in any way, this paper has benefited from discussions with John Bound, Charlie Brown, John DiNardo, David Lam, James Levinsohn, Justin McCrary, Jeffrey Smith and Gary Solon. We are very grateful to Nicola Branson for sharing her data on LFS sample weights with us.
} 


\section{Introduction}

What happens to wages and employment in the informal sector after the introduction of a minimum wage in that sector? The vast minimum wage literature in economics has remarkably little to say on this question, since the informal sector has more often represented the uncovered sector in this research and has been used to help distinguish between models of the labor market. For example, if the wage and employment effects of a formal sector minimum are mirrored by opposite-signed responses in the informal sector, this is consistent with a segmented two-sector labor market model. ${ }^{1}$ However, if informal sector wages increase (and employment decreases) when a formal sector minimum is adjusted upwards, this is consistent with spillovers in an integrated labor market, or possibly with "lighthouse effects". ${ }^{2}$ In this paper, we extend the minimum wage literature and investigate whether a minimum wage floor can have any effect when directly applied to the informal sector, where the institutional environment for monitoring and enforcement of penalties is weak. We use the introduction of the first minimum wage in South Africa's domestic worker sector in November 2002 to analyze what can happen in the short-run.

Whether a minimum wage can have any impact in the informal sector is broadly relevant for understanding more about the process of labor market formalization in developing countries. As economies develop, labor relationships shift from rural to urban areas and take place in larger and larger firms; employees or their employers start to pay taxes and workers gain legal protections, often including a guaranteed minimum rate of pay. Such protections, when enforced, may improve working conditions and reduce poverty among the least skilled workers (Lustig and McLeod (1997) summarize results from several studies), or may hinder the operation of markets and negatively affect productivity (as in Besley and Burgess, 2004) and employment. ${ }^{3}$ For many developing countries contemplating such regulation, resources for monitoring and enforcement are limited. Most economic models of employer behavior require some penalty and a non-zero probability of being audited to predict any effects of minimum wage regulations (see Ashenfelter and Smith (1979) for the canonical model of minimum wage compliance). ${ }^{4}$ A first-order question for many developing countries then is:

\footnotetext{
${ }^{1}$ See Brown (1988) for a discussion of two sector models in minimum wage studies.

${ }^{2}$ Spillover effects into the informal sector or other formal uncovered sectors have been documented by many researchers, particularly in Latin American countries. See Lemos (2009) for Brazil, Gindling and Terrell (2004) for Costa Rica, Maloney and Menendez (2004) for a variety of Latin American countries, Bell (1997) for Mexico and Colombia. See also Cortes (2004) for the USA. Brown (1988) notes that in the US, a large fraction of workers earn the minimum wage, even though they are employed by establishments not subject to the minimum wage law.

${ }^{3}$ In that paper, Besley and Burgess (2004) show how active and costly pro-worker regulation in the formal manufacturing sector in India led to increased informality, reduced investment and lower labor productivity.

${ }^{4}$ Despite the greater availability of resources for enforcement in developed countries, non-compliance
} 
what effects can be expected from new labor legislation that is not monitored or enforced?

In this paper, we shed light on the effects of new labor regulation in a context without active enforcement or clear penalties. We present an empirical example in which domestic work employers face an extremely high minimum wage (set at the $70^{\text {th }}$ percentile of the pre-law wage distribution) with no effective penalties and no monitoring, and show that employers still choose to respond to the law. We document immediate, large and partial adjustment of wages upwards in the wake of the law and find no significant effects on the intensive or extensive margins of work, at least in the short-run, 16 months after the law is introduced. ${ }^{5}$ We also show dramatic increases in the fraction of domestic workers who have a formal contract of employment, after the law. This South African case indicates that labor legislation may not require a degree of market formality in order to be effective; rather, the introduction of the law may serve as a focal point for shifting markets in the direction of becoming more formal. ${ }^{6}$

The domestic work sector is important in its own right, and is under-studied given its prevalence over space and time. Historically, this sector has been important in developed countries. Rubinow (1906) uses census data to show that over 1.2 million women were employed in domestic work in the US in 1900. World-wide, the market for domestic workers currently employs many millions of women: foreign workers employed in private households currently make up around $10 \%$ of the labor force in a number of Middle Eastern countries (Kremer and Watt, 2006); Cortes and Pan (2009) document that foreign domestic workers constitute $6 \%$ of the workforce in Hong Kong; while ILO data for OECD countries record an average of 100,000 female domestic workers per country. The UK and Germany are at the high end of this range with 400,000 and 460,000 female domestic workers respectively.

with minimum wage laws is widespread. Ashenfelter and Smith (1979) note that compliance with the US Federal minimum wage was only $65 \%$ in 1973; Cortes (2004) reports that in 1997, as many as $40 \%$ of US workers who qualified were paid less than the minimum wage; and non-compliance rates in excess of $50 \%$ have been reported for Mexico, Morocco (Squire and Suthiwart-Narueput 1997) and other developing countries. See Neumark and Wascher (2007) for a comprehensive review of the literature on minimum wages from developing countries. All of the theoretical literature on compliance with a minimum wage hinges on employers choosing an optimal level of compliance in the face of penalties and enforcement. See Grenier (1982), Chang and Ehrlich (1985), Bloom and Grenier (1986), Chang (1992), Lott and Robert (1995) and Weil (2005).

${ }^{5}$ One benefit of focussing on short-run effects is that there is little time for workers to sort across areas and relocate e.g. from rural to urban areas in search of higher wage jobs. In our data, roughly the same fraction of domestic workers report starting their current job in the past year, both before and after the law (12\% in September 2001 and 14\% in September 2003). The remainder had longer tenure. Unfortunately, we are unable to analyze tenure length in this paper, as this information was not collected in every year of the survey.

${ }^{6}$ The first minimum wage law introduced in the US in 1912 (in Massachussetts, for women) had some similar features to our setting. One penalty involved newspapers "naming and shaming" non-compliant firms by publishing their names (Thiess, 1991). 
In South Africa, close to one in five women- about one million women- work as domestic workers.

In most of these labor markets, the domestic work sector clearly fits the ILO's definition of 'informal', as it consists of one-employee enterprizes (households) in which labor relations are predominantly uncontracted and without formal minimum wage or other protections. The small scale of employers makes this sector costly for unions to organize. ${ }^{7}$ Work often extends beyond simple housekeeping services and can require a great deal of trust, particularly when child-care is involved or when the employer is absent during working hours. Additionally, and particularly in Asia, Latin America and the USA, domestic workers are often foreign migrant workers with tenuous legal status. This increases their vulnerability in the labor market. ${ }^{8}$ For example, in the USA, domestic workers are largely undocumented and are not yet guaranteed all of the protections of the National Labor Standards Act (e.g. they are not currently entitled to overtime pay). ${ }^{9}$ We believe our analysis of the South African case sheds light on the short-run effects of introducing minimum wage legislation to these informal and uncovered work relationships that are globally prevalent.

The empirical exercise in this paper is straightforward. We evaluate the effects of South Africa's 2002 minimum wage law for domestic workers by exploiting time-series variation in the application of the law and pre-existing cross-sectional variation related to the intensity of the law to identify wage and employment effects. We use six waves of a biannual labor force survey (LFS) from 2001 to 2004 to capture worker-reported wages, hours of work and employment over time at relatively high frequency. Large shifts in the wage and earnings distributions of domestic workers are evident in non-parametric kernel densities. We complement this with an analysis that adopts the methods in Lee (1999). ${ }^{10}$ We combine the

\footnotetext{
${ }^{7}$ The ILO defines "informal employment" as "all remunerative work (i.e. both self-employment and wage employment), that is not registered, regulated or protected by existing legal or regulatory frameworks, as well as non-remunerative work undertaken in an income-producing enterprize. Informal workers do not have secure employment contracts, worker's benefits, social protection or workers' representation" (http://www.ilo.org/public/libdoc/ILO-Thesaurus/english/tr1746.htm).

${ }^{8}$ This idea of heightened vulnerability is not new. In 1906, Rubinow (1906) writes about the "servant girl's problem" and describes American preferences for hiring foreign women for domestic work as being related to the "greater ease of managing them", which translates into "longer hours, perhaps lowers wages, more work and, in general, conditions of service more favorable to the employer".

${ }^{9}$ Recently, the state of New York became the first state in the USA to sign into law a Domestic Workers Bill of Rights. Among other rights, the new law ensures that domestic workers have notice of termination, receive paid sick days and holidays, and other basic labor protections that are standard in the Fair Labor Standards Act. See the editorial "The Rights of Domestic Workers", The New York Times June 15, 2009. httP : //www.nytimes.com/2009/06/15/opinion/15mon3.html Also the article "Senate Passes Historic Bill To Protect Domestic Workers" at http ://www.nysenate.gov/press - release/senate - passes - historic bill - protect - domestic-workers posted on June 2, 2010.

${ }^{10}$ In that paper, Lee (1999) uses regional differences in the relative level of the US federal minimum wage to identify the effects of the minimum wage law on wage inequality in the 1980s, separately from the effects of national trends in wages.
} 
before-after variation in the law with cross-sectional variation in the intensity of the minimum wage law to implement a difference-in-differences strategy to statistically examine the effects of the law. Using just the before-after variation, the analysis shows that domestic worker wages increase by about $20 \%$ in the 16 months after the law. Comparing the change in wages (and hours of work) of domestic workers in places where the median wage was far below the wage floor in the pre-period, to places where the median wage was closer to the minimum, we find that wages increased by a significant and additional 10-15\%, post-law. In contrast, we find no significant reduction in hours of work (although measurement error in this variable makes it difficult to precisely estimate any hours effects), nor any significant change in the probability of a low-skilled female worker being employed as a domestic worker in the pre- versus post-period, in high wage gap compared to lower wage gap areas. ${ }^{11}$

In the typical difference-in-differences research design that exploits a change in policy at one point in time, a key identification assumption is that both the exposed and unexposed groups are on the same trend in the absence of the policy change. In our scenario, all areas are exposed to the law, but we make use of the fact that this law is more demanding of employers in areas with lower pre-law wages. However, since the minimum wage is set so high in the pre-law wage distribution, we expect to see (and do find) that domestic workers in all areas experience higher wages in the immediate months after the law. Unlike other difference-in-differences approaches to minimum wage policy changes, we are interested in the simple pre-post "difference" in wages as a potential outcome of the new law. To provide evidence that the generalized wage increases we find for all domestic workers is not solely the result of economy-wide shocks, we perform one placebo experiment. We estimate the difference-in-differences specification for a set of similar workers who are unlikely to compete over jobs with domestic workers, but whose job conditions likely reflect general economic conditions: low-skilled male manufacturing workers in urban areas. We find that in the period after the law, male manufacturing wages increase by about $10 \%$, suggesting some improvement in the economy after 2002. However, we can reject that these pre-post changes for manufacturing workers are the same as for domestic workers: domestic workers as a group still experience a significantly larger gain in wages $(10 \%)$ in the period after the law. Furthermore, we find no evidence that wages for male manufacturing workers rise more in areas where the minimum wage law was more binding on domestic workers. This gives us more confidence that the difference-in-differences results we estimate for domestic workers are not being driven by differential wage trends between high and low wage gap areas.

\footnotetext{
${ }^{11}$ While there are changes in the observable characteristics of domestic workers after the law, adjusting for this compositional change does not account for the entire shift in the distribution of domestic worker wages in the wake of the law. We show this in an appendix.
} 
One limitation of our analysis is that the data do not allow us to rule out that employers achieved these wage increases by making offsetting reductions in non-wage in-kind benefits. These benefits, mainly in the form of free food, were fairly substantial for some workers before the law, as we describe. In order to show that the new law did have a substantive impact on the conditions of work for domestic workers (outside of any wage increases), we also examine the probability that a domestic worker has a formal job contract with their employer, after the law. We find that the probability of an employee having a formal contract doubles in the 16 months after the law, regardless of the intensity of the minimum wage floor in their area of work. This evidence on contract coverage reflects the beginning of the formalization of this industry, which could have far-reaching consequences for the nature of domestic work in the country.

Given the weak institutional environment for enforcement of the law, which we describe, it is somewhat surprising that we see such large wage responses and no employment effects in this informal sector. Isolating the exact reasons for the employer response is not easy; however, we propose two pieces of evidence that suggest that employers were voluntarily and only partially responding to the law. First, we develop a test for partial compliance, which shows that some workers get increases bringing their wages closer to, but not nearly up to, compliant levels. This partial compliance probably contributes to the lack of employment effects of the law. ${ }^{12}$ Second, we show that the wage response of employers is not significantly different across places with different audit probabilities, where we use the presence of a local Labour Centre (LC) as a proxy measure of this probability. Partial compliance that does not appear responsive to the likelihood of audit is consistent with the idea that employers may not have been primarily motivated by threat of external sanctions.

Two related and unpublished papers have examined the effect of the minimum wage law for domestic workers in South Africa: Hertz (2006) and Yamada (2007). Our study differs from these studies in several dimensions. First, we focus on urban workers only, because we believe that identification of the impact of the new minimum wage law for rural domestic workers is likely confounded by the concomitant introduction of a minimum wage for agricultural workers, a plausible alternative sector for low-skilled workers in rural areas. ${ }^{13}$ Second, we use an updated and consistent set of survey weights for the LFS data (Branson, 2009) which were not available for these studies. ${ }^{14}$ Third, we use a higher level of aggregation

\footnotetext{
${ }^{12}$ This finding relates to a theoretical point made in a recent paper by Basu, Chau and Kanbur (2007). The authors develop a model in which governments accept some non-compliance with minimum wage legislation to achieve distributional goals.

${ }^{13}$ Agricultural workers received protection under a minimum wage law, also for the first time, 6 months after the domestic worker minimum wage floor was imposed.

${ }^{14}$ Details of this choice are discussed in the data section.
} 
(the province) to define areas in which the new law was more or less binding, based on prelaw characteristics. This choice presents other challenges for inference, which we describe in detail in our empirical approach section. ${ }^{15}$ Our results for the wage effects of the minimum wage law turn out to be quite a bit smaller than the estimates in Hertz (2006) and Yamada (2007) and, unlike these studies, we find very little evidence for a negative employment effect of the law on either the intensive or extensive margins of work.

The paper begins with a description of the domestic worker industry in South Africa before the law and describes the characteristics of the new law introduced in 2002. After describing the data and presenting summary statistics of our sample, we turn to documenting the wage, earnings, employment and hours of work effects of the law using a combination of kernel densities for wages and earnings and difference-in-differences regressions. We discuss our test for and present evidence of partial compliance with the law. We show that wage increases are not larger in places with higher probability of audit, and that the law increased the probability of a domestic worker having a formal employment contract, regardless of how large the initial wage gap in the province of residence was. We conclude with a discussion and interpretation of results.

\section{The domestic worker industry in South Africa}

The domestic worker industry in South Africa employs $18 \%$ of all women, and $80 \%$ of all domestic workers are female. Poorly educated African and coloured women make up the vast majority of these domestic workers. ${ }^{16}$ In each year of our study, about $15 \%$ of urban African and coloured female workers were in the domestic work sector. Unlike many Latin American and Middle Eastern settings, and more like countries in the rest of Africa and parts of India, the majority of domestic workers in South Africa are not foreigners. Table 1 presents means and standard deviations of female domestic worker demographics for each survey period before the law is enacted (September 2001, March 2002), the "cusp" survey wave of September 2002, and the three surveys after the law (March 2003, September 2003 and March 2004). All statistics are weighted, and the data sources are described in more detail in the next section.

\footnotetext{
${ }^{15}$ Hertz's 2006 working paper uses some of the same LFS cross-sectional data to estimate the impact of the law on wages and employment using a difference-in-differences approach that relies on a much smaller unit of analysis (the magisterial district). He relates the intensity of the minimum wage law to the fraction of workers in a magisterial district who initially earned below the minimum (following Card and Krueger, 1997). We choose not to use magisterial districts as the unit of analysis, since many districts contain only a few (under 10) individuals in each wave who are employed as domestic workers.

${ }^{16}$ Following much of the economic literature on South Africa, we use apartheid-era racial classifications: African for Black South African, and coloured for individuals of mixed race.
} 
Immediately obvious from Table 1 is the remarkable stability of worker characteristics in this industry. About $60 \%$ of domestic workers are urban workers, and within the urban group - our sample of interest - the average age of workers is around 40. The majority are African and have between 6.3 and 7.1 years of education (completed primary school). This is 0.8 to 2 years below the average education of women working in the most closely related skill-groups: women in elementary occupations (e.g. newspaper vendors, office cleaners, hawkers, building caretakers, garbage collectors etc) and the female self-employed. $76 \%$ or more of domestic workers report working full-time, defined as 28 hours or more per week, making the majority subject to the full-time minimum wage.

Domestic workers are poorly remunerated. Mean wages are lower in this occupational group than in any other: the ratio of the mean domestic worker wage to the mean wage for other low-skilled African and coloured elementary workers (self-employed women) was 0.49 (0.64) in September 2001. Prior to November 2002, there was no minimum wage in the domestic worker sector and no formal mechanism existed for domestic workers to negotiate wages. Wages were typically set unilaterally by the employer household or in consultation with other local employers (see Cock (1989) for a qualitative description of this process). Some aspects of the 1997 South African Basic Conditions of Employment Act governed overtime provisions, leave considerations, minimum notice periods, fair dismissal procedures and severance pay for all workers (Department of Labour, 1997). However, these were rarely adhered to in this informal market (Louw and Van der Berg, 2004). Only 10\% of domestic workers had a formal contract of employment in 2001, compared to $55 \%$ of elementary occupation workers.

Remuneration for domestic work often combines cash and in-kind benefits. In another survey (the 2000 South African Income and Expenditure survey, results not shown) which captures information from employers about the value of food, clothing, accommodation and unemployment benefits provided to the worker, about $25 \%$ of domestic worker employers report providing the employee with some housing; $3 \%$ report unemployment insurance (UI) benefits, $34 \%$ report some clothing provided to the employee, and the vast majority of employers, $80 \%$, report providing free food to employees. Averaging over all domestic worker households, we find that the fraction of total remuneration accounted for by these benefits is low for UI (0.6\%), clothing (6\%) and housing (5\%), and highest for food (20\%). ${ }^{17}$ Since a large fraction of total remuneration comes from in-kind benefits before the law, it is plausible that employers may adjust benefits downward to afford the wage increases. This will be an

\footnotetext{
${ }^{17}$ We get these fractions by dividing the employer-reported value of food, accommodation, clothing and UI provided per month by the total monthly remuneration (cash plus benefits) reported by the employer. The more recent IES in 2005/2006 does not contain these data and so we cannot compare how these in-kind benefits may have changed over time.
} 
important caveat to the interpretation of our wage results.

In setting the first national minimum wage for domestic workers, the Department of Labour (DoL) took into account the recommendations of a government-appointed Employment Conditions Commission. This group of government representatives and academics defined the scope of the Domestic Worker Sector and concluded that any wage floor should "improve the livelihoods of those worst off" and "retain jobs". Their recommendation for the actual minimum wage level was higher than that initially proposed by the government, and was the one eventually adopted (Budlender et al, 2002).

Under the new law, which became effective on 1 November 2002, domestic workers and gardeners working in private homes had the right to a minimum wage and to $8 \%$ annual wage increases. ${ }^{18}$ The urban full-time hourly minimum wage was set at ZAR4.10 (USD 0.410) in November 2002; the part-time wage was ZAR4.51 (USD 0.451) where part-time work is defined as fewer than 28 hours per week. In addition, the new law enabled employers to deduct up to $10 \%$ of the total salary for rental value of any accommodation provided. A separate and related piece of legislation, introduced shortly afterwards on April 1, 2003, additionally required employers to register domestic workers with the DoL in order to pay unemployment insurance (UI). ${ }^{19}$

It is important to note that the changes introduced in this industry are an order of magnitude larger than typical changes in the value of the minimum that economists typically study: the wage floor was set at 1.5 times the median monthly earnings of domestic workers in 2002. Full compliance in this context would have entailed massive wage increases for a majority of workers and potentially large employment effects for most employees either on the extensive or intensive margin. Given existing high levels of unemployment in South Africa, this would be one possible reason for why the government did not commit substantial resources towards enforcement of the law.

In fact, in the first ten months after the law, both the audit probability and penalty for first time violators were very small. ${ }^{20}$ As far as we have been able to establish, no

\footnotetext{
${ }^{18}$ Garden workers, most of whom are men, are also covered as domestic workers under this law. However, they make up a minority of domestic workers and so we omit them from our analysis.

${ }^{19}$ The average Rand/USD exchange rate from June 2002-January 2003 of ZAR10=USD1.

${ }^{20}$ During this time, employers might have expected a vanishingly small audit probability for two reasons. First, the chances of random inspection are small since inspections are labor intensive and each household yields only a single worker inspection. If each domestic worker works in only one household, this yields over one million employers that are subject to the minimum wage law. Second, logistical difficulties in gaining access to employer premises make any inspection costly. A non-compliant employer can legally refuse to allow an inspector into their private residence, or simply not be present at the time of the inspection. A court order from a Labor Court is then required to enter the residence. There are also physical barriers to entry: inspectors have reported difficulties with impenetrable gates and "the presence of dogs" (Official release by the DoL, $27^{t h}$ August 2003. Available at www.labour.gov.za).
} 
inspections were carried out until August 2003, ten months after the law. At this time, 1,600 households in five provinces were earmarked for inspection and $25 \%$ of them were found to be in compliance with the law. ${ }^{21}$ We have not been able to obtain further statistics on household inspections from the DoL.

There were also no documented rules about penalties or back-pay for non-compliers at the time of implementation. Press releases from the DoL in February 2003 indicated that "Non-compliance with the UI law will result in penalties of up to ZAR5,000 (USD500) per household or five years imprisonment" ${ }^{22}$. However, we have not been able to find formal documentation of this or other penalties, nor has our search of newspaper archives revealed any reports of fines or prison sentences being imposed on non-compliant employers. ${ }^{23}$ What we do know is that non-compliers might have expected three progressively more threatening warnings (telephonic, written, court order) before appearing at a court of law. At this time, they would have had a right of appeal, which would be well exercised as it is unclear how evidence for non-compliance would be substantiated in this predominantly cash payment industry. ${ }^{24}$

All evidence from the DoL website and various legal documents and reports related to the law suggest that the general monitoring and enforcement regime in the domestic worker industry was weak and presented employers with an almost zero expected cost of non-compliance. Despite this lack of compliance incentive, the timing of the law coincides with substantial rightward shifts in the wage and earnings distributions of domestic workers. We document this after describing our data.

\section{Data description and empirical methods}

\subsection{LFS Surveys}

We use six cross sections of data from the nationally representative South African Labour Force Surveys (LFS): September 2001, March 2002, September 2002, March 2003, September 2003 and March 2004. These LFS surveys are biannual rotating panel surveys, conducted in February/March and September each year and include detailed data on work and unemploy-

\footnotetext{
${ }^{21}$ See media release at www.labour.gov.za/media/statement.jsp? statementdisplay $y_{i} d=9685$

${ }^{22}$ http://www.info.gov.za/speeches/2003/03050809461001.htm

${ }^{23}$ The Basic Conditions of Employment Act (1997) which covers all formal sector workers states that underpayment violations are penalized in the following manner: first offence - $25 \%$ of the gap plus interest; second offence within 3 years - $50 \%$ of the gap plus interest; third offence within 3 years or second offence within 2 years - $75 \%$ of the gap plus interest; fourth offence within 3 years - 100\% of the gap plus interest; fifth offence within 3 years - $200 \%$ of the gap plus interest.

${ }^{24}$ Pay slips are now required as part of the minimum wage legislation.
} 
ment experiences of 60,000 to 70,000 working-age individuals living in 30,000 households. The six waves we use span the period just before and just after the minimum wage law becomes effective in November 2002. The survey instrument is similar to the US Current Population Survey, although the rotation pattern differs. In each wave, $20 \%$ of households interviewed in the previous wave are rotated out of the survey entirely. ${ }^{25}$ These LFS data are high frequency and can be used to examine differences over a six month window. They help us to estimate the immediate impacts of the law while controlling for observable characteristics of domestic workers (i.e. age, race and years of education) and to see whether preversus post comparisons are sensitive to these controls. We also model the probability of being employed as a domestic worker in each wave, using the set of employed and unemployed women with similar age and education profiles to domestic workers. We use these LFS data as repeated cross sections and exploit the cross-sectional variation in intensity of the law at the province level (9 provinces in total) in combination with the time-series variation in the law's intensity to identify the effects of the law. ${ }^{26}$

\subsection{Sample weights}

One further aspect of the data that is worth noting concerns the appropriateness of the sample weights available in the LFS. Survey weights for LFS 2001 and 2002 are benchmarked to the 1996 Census; while survey weights for LFS 2003 are benchmarked to the later 2001 Census. With different benchmark years, this series of weights is potentially inconsistent over time. Hertz (2006) provides a detailed discussion of how these inconsistencies in the weights may affect any analysis of the minimum wage law. He points out that the 2001 Census under-counted the fraction of women of working age and that the extrapolations between 1996 and 2001 overestimated growth in the adult population by underestimating the effect of the HIV epidemic on adult totals. He notes that "no consistent official series of sampling weights is available. This poses a serious problem, as both the changes in scale and

\footnotetext{
${ }^{25}$ Although there are three earlier waves of data going back to 2000, the baseline sample was drawn anew for the September 2001 round which is why we begin our analysis with data from this round. And, although the LFS survey has continued biannually since March 2004, we cannot use additional waves of post-data in our analysis since the survey stopped reporting whether the individual resides in an urban or a rural area, thus making it impossible for us to condition our sample on urban domestic workers.

${ }^{26}$ There is a panel data component of the LFS survey, but we have some concerns about the representativeness and quality of the panel data set of workers. First, since the design of the panel includes a $20 \%$ out-rotation of dwellings in each six month period, in order to appear in the panel a worker needs to be living continuously in the same place for six waves and needs to escape the out-rotation group. We expect that workers who are more likely to retain employment are also more likely to appear in the panel, making the estimation of the effects of the law on such a selected sample difficult. Second, we learned from Statistics South Africa (the organization that collects the LFS data) that some panel matches could not be made, because some fraction of questionnaires from the pre-period were lost in a flood. We have no way to know what impact this would have on the representativeness of the panel.
} 
the changes in the age, gender, province, and race group distributions result in artifactual changes in the measured employment of domestic workers that are too large to be ignored." Indeed, the original sample weights that he refers to have been shown to produce inconsistent aggregate statistics over time. More formally, Branson (2009) explains that "The StatsSA weights presented in the data are problematic for analyses over time ... the auxiliary data used as a benchmark in the post-stratification adjustment are unreliable and inconsistent over time and hence result in temporal inconsistencies even at the aggregate level."

For these reasons, we do not use the weights provided with the LFS data. Rather, our results use new (individual-level) survey weights that have been constructed by Nicola Branson (2009) using entropy estimation. ${ }^{27}$ These weights produce "consistent demographic and geographic trends", as Branson (2009) shows.

\subsection{Sample selection, key variables and empirical strategy}

Our sample of workers includes all urban African and coloured woman aged 20 to 59, who report domestic work, who do not also own their own business and who have no more than high school education. For the employment analysis, we use an expanded sample of all African or coloured woman aged 20 to 59 who live in urban areas, who have no more than a high school level of education and who are employed or looking for work. For the placebo test, we make use of a sample of male urban African and coloured workers, aged 20 to 59, who have no more than a high school education and who report working in the manufacturing sector.

In the LFS, all workers are asked about earnings, pay frequency and usual weekly hours of work. Most workers report earnings and a corresponding pay frequency. The vast majority$89 \%$ of domestic workers - report a monthly pay frequency. We convert all earnings to monthly amounts using the pay frequency information. About 8-9\% of domestic workers in any one wave do not report earnings at all and we exclude these individuals from our analysis. ${ }^{28}$ To capture hours of work, we use the response to the question "How many hours do you usually work in a week?" We construct hourly wage measures by dividing monthly earnings by monthly hours. We construct monthly hours as Usual hours worked per week*Average weeks in a month. Just over $5 \%$ of workers report working more than 70 hours a week and we exclude these individuals from our analysis.

\footnotetext{
${ }^{27}$ These methods are described in Branson (2009). Briefly, the idea is to create a new set of weights that are as close to the original weights as possible (to preserve the main features of the sample design) but that are adjusted to account for errors arising from time inconsistent benchmarks, from inconsistencies between household and person weights, and for errors in the trimming of weights in earlier survey years. We are grateful to Branson for making these weights available to us.

${ }^{28}$ The fraction of domestic workers with no earnings information is not significantly different across waves.
} 
We describe the impact of the minimum wage law in two ways. First, we estimate nonparametric kernel densities of domestic worker wages and earnings and test for differences in the domestic worker distributions over time using Kolmogorov-Smirnov tests of the equality of distributions. Then, we statistically test for whether outcomes changed in the period after the law compared to before the law, and for whether these changes are larger in areas where the minimum wage initially had more "bite". We specify the following difference-indifferences regression model:

$$
y_{i j t}=\alpha_{0}+\alpha_{1} P O S T_{t}+\alpha_{2} W G_{j}+\alpha_{3} P O S T_{t} * W G_{j}+X_{i j t} \gamma+\nu_{i j t}
$$

where $y_{i j t}$ is one of four main outcome variables for individual $i$ living in province $j$ in period $t$ : log hourly wages, weekly hours of work, the possession of a formal job contract for the set of domestic workers, and whether the individual is employed as a domestic worker or not, among the set of demographically similar women. Equation (1) is estimated with and without controls for worker characteristics $\left(X_{i j t}\right)$, including age, years of education and an indicator variable for whether the person is African. We group data from the September 2001, March 2002 and September 2002 surveys into a "Pre" period and the remaining three waves into the "POST" period. Because the law was formally announced on August 30, 2002, but employers were only expected to be compliant from 1 November 2002, there is some ambiguity about whether the September 2002 wave belongs in the pre- or post-period. There was substantial publicity in the months prior to the law becoming effective, making it plausible that some employers started to react even before the November 1st deadline. For this reason, we also present results from regressions that omit the September 2002 cusp wave, for which "POST $T_{t}$ " is not well-defined. These are our preferred estimates.

To construct a measure of the intensity of the minimum wage law, we follow other examples in the minimum wage literature (notably Lee, 1999) that use aggregate (rather than individual) data on workers over time and construct a locally-specific wage gap using data on wages from the "PRE" period. We define the province-level wage gap as:

$$
W G_{j}=\log [\min (w)]-\log \left[\operatorname{median}\left(w_{j}\right)\right]
$$

where $\min (w)$ is the urban full-time minimum wage in November 2002 and median $\left(w_{j}\right)$ is the median wage of all urban domestic workers in the province before the law. That is, the intensity of the minimum wage law is measured according to domestic worker conditions in local labor markets in September 2001 and March 2002.

The parameter $\alpha_{2}$ represents the average difference in outcomes for domestic workers in low wage gap versus high wage gap areas across the entire period. $\alpha_{3}$ is the difference-in- 
differences parameter and tells us how much more outcomes changed, in areas where the minimum wage was most binding. In order for $\alpha_{3}$ to identify the effect of the minimum wage law in high $W G_{j}$ areas, we must assume that in the absence of the law change, low wage gap provinces would be on the same trend in outcomes as high wage gap provinces.

In addition to $\alpha_{3}, \alpha_{1}$ is also a parameter of interest as it tells us how wages (and other outcomes) for domestic workers changed on average after the law. In most difference-indifferences analyses this parameter is not directly of interest and the $P O S T_{t}$ variable is included simply to absorb common, contemporaneous shocks to outcomes or common trends. However, in the context of this study, the minimum wage floor cuts so high in the distribution of domestic worker wages that we expect at least a portion of $\alpha_{1}$ to reflect the impact of the law on average domestic worker outcomes. This claim is, of course, difficult to make in the absence of evidence on economy-wide trends in other wages. So, as a placebo test, we implement the same regression model as in (1) for a set of workers for whom the minimum wage law is irrelevant and who do not directly compete with domestic workers for jobs. These workers are male, low-skilled manufacturing workers in urban areas. The minimum wage law for domestic workers does not apply to them and, moreover, is set at a level far below their median wage. Changes in male manufacturing wages and hours of work give us some indication of what is going on in the South African economy at the same time as the new minimum wage law comes into place. We will be interested in testing whether $\alpha_{1}$ and $\alpha_{3}$ are the same for the sample of manufacturing workers and domestic workers. If $\alpha_{1}$ is different, this implies that the coefficient on $P O S T_{t}$ in the domestic worker regression captures some of the impact of the new law, over and above any economy-wide shocks to wages. If $\alpha_{3}$ is different, this implies domestic worker wages (or other outcomes) are changing more in high wage gap relative to low wage gap areas, and that these differential changes are not simply a reflection of broad trend differences across high wage gap and low wage gap areas.

Note that our measure of the intensity of the law, $W G_{t}$, is captured at the provincial level. This means that in estimating (1), we exploit variation at the group (province) level to identify the effects of the law. The fact that there are only nine groups (provinces) presents a challenge for inference. Consider the following error components model for the error term $\nu_{i j t}$ in $(1)$ :

$$
\nu_{i j t}=v_{j}+\epsilon_{i j t}
$$

Standard OLS without adjustment of the standard errors treats each individual as if they contribute equally and independently to the variation in outcomes. Since $\sigma_{\nu}=\sigma_{v}+\sigma_{\epsilon}$ and $v_{j}$ is the same for each individual in the same province (the main policy change occurs at 
an aggregated level), this approach overstates the amount of variation in our data. The situation is not quite as dire as only having nine observations, since we also have individuallevel control variables that differ within provinces and which account for a large part of the variation in outcomes. However, it is clear that some adjustment for the grouped nature of the error term is called for.

We take two approaches. First, we follow the common recommendation in the literature to estimate Eicker-White clustered standard errors at the level of the group (province). ${ }^{29}$ However, the standard asymptotic arguments for the consistency of clustered standard errors may not apply with the small number of groups in our context, even given the additional variation found in the demographic controls. We still run the risk of underestimating standard errors (and over-rejecting the null) using this approach.

As a second approach, we follow Donald and Lang's (2007) suggestion and implement their two-step estimator which, under some conditions, produces standard errors that appropriately take into account the group-specific term in (3). To implement this, we first regress outcomes on all individual level variables, the $P O S T_{t}$ variable, a full set of province dummy variables and a full set of $P O S T_{t}{ }^{*}$ province interaction dummy variables. Then, we take the estimated coefficients from these province indicators and from the $P O S T_{t}{ }^{*}$ province interaction terms and use them as the outcomes in a second stage regression. This second stage involves regressing the estimated coefficients on a $P O S T_{t}$ indicator, the $W G_{j}$ measure and the interaction $P O S T_{t} * W G_{j}$. The resulting standard errors from this second stage model are calculated with the group-component of $\sigma_{\nu}$ taken into account and, together with the second stage coefficients, form t statistics that have the $t$ distribution when the number of groups is small. ${ }^{30}$ There is a nice intuition for this estimator: the first stage regression produces estimates of the group-level means in the post-period (these are the coefficients on the province indicator variables and the $P O S T_{t}{ }^{*}$ province interactions) after taking into account variation in the other individual controls. In the second stage, we estimate how much of this variation in these group-level (estimated) means is predicted by variation in $P O S T_{t}, W G_{j}$ and $P O S T_{t} * W G_{j} \cdot{ }^{31}$

\footnotetext{
${ }^{29}$ This approach to estimating appropriate standard errors in a difference-in-differences specification is discussed in Bertrand, Duflo and Mullainathan (2004) and in Donald and Lang (2007), among others.

${ }^{30}$ The conditions required for this result are that the number of individuals in each province is large and that the underlying $v_{j}$ 's are normally distributed. We must assume the latter condition, and have at least 600 observations in each "group" giving us some confidence in the former condition. For more details on this procedure, see Donald and Lang (2007).

${ }^{31}$ In the absence of demographic or other controls that vary within province, this two-step estimator is equivalent to collapsing the data to the province-year level and estimating a form of the difference-indifferences specification on these province-level means. However, we use the two-step estimator here to take advantage of the fact that we have individual level controls that do matter for outcomes, while not overstating the amount of policy variation we have to identify the impact of the law.
} 
In addition to the graphical evidence from the kernel densities and the difference-indifferences statistical tests, we implement two tests to investigate the mechanisms through which the new minimum wage law had an effect. We are particularly interested in understanding whether or not employers are complying with the law primarily because they are concerned with penalties and external enforcement.

Our first test shows that there is only partial compliance with the law. That is, some employers are responding to the law, but their response is insufficient for compliance. In the absence of individual-level panel data which we could use to test whether a worker experiences only partial wage adjustment to the law, we devise a related test for partial compliance using repeated cross-sections. First, we classify domestic workers into each of three bins, where the 'near compliant' bin consists of workers earning the minimum or up to $10 \%$ below the minimum, the 'compliant' bin contains all workers who earn above the minimum and the non-compliant bin contains workers that are earning more than $10 \%$ below the minimum. We estimate an ordered probit model of the log of hourly wages on a constant, a $P O S T_{t}$ indicator and a set of demographic and geographic controls (in a first specification) and then also include controls for the wage gap and the $P O S T_{t} * W G_{j}$ interaction (in a second specification). We then predict the relevant marginal effects to estimate the change in the probability of being in the 'near compliant' bin and test for whether this change is positive. Appendix 1 sets out the details of how we derive this test as the relevant one for partial compliance. The intuition behind the test is that if the probability of workers reporting wages in the non-compliant bin falls by more than the probability of workers reporting wages in the compliant bin rises, then some workers are earning more than they were before (shifting to the near-compliant region), but not enough more to make them compliant with the law. Such a result would be consistent with an argument whereby employers are responding, but not because they are law-abiding. Note that this interpretation of the test relies on there being no large employment adjustment to the law, a fact that our earlier estimates demonstrate.

Our second test shows that the size of the wage effect is not related to a proxy for the probability of being audited by the DoL. Although we have described above how the probability of being monitored was very small, it is still possible that domestic workers themselves may have threatened to report non-compliant employers to the authorities. Indeed, Hertz (2006) reports an immediate increase in the number of domestic worker complaints made to the Commission for Conciliation, Mediation and Arbitration (CCMA) after the law is introduced. The relevant labor authorities we consider here are housed in local LCs. We use the presence of an LC in the worker's local labor market as a proxy for higher probability of audit, and we control for this proxy and its interactions with $P O S T_{t}, W G_{j}$ and $P O S T_{t} * W G_{j}$. Here, the local labor market is defined as the magisterial district in which 
the domestic worker resides; which is a more disaggregated measure than the province. If employers respond to the law because they fear external enforcement, we should see wages rising by more in places with an LC, compared to places without.

\section{Results}

\subsection{Before-After and Difference-in-Differences comparisons}

The introduction of a minimum wage in the domestic worker industry appears to have had immediate and substantial effects on earnings and wages of the average domestic worker, yet limited effects on hours of work. Table 1 shows the large jump in mean wages and earnings between September 2002 and March 2003 (16 cents and 48ZAR respectively) and an even larger increase by March 2004 (70 cents and 124ZAR). In the 16 months after September 2002, nominal monthly earnings increase by $22 \%$ and nominal wages by $18 \%$. In a market that was previously experiencing decreases in nominal wages in September 2001 and March 2002 , this is a phenomenal increase in a very short space of time. The fraction of workers paid above the minimum increases from about one-quarter in September 2001 and March 2002 , to $45 \%$ in the last wave of the data.

Another striking result from Table 1 is that the variance of wages and earnings in the post periods indicate a significant increase in dispersion relative to the pre-period. This is unusual, since wage compression is typically observed in response to increases in binding minimum wage laws. This stretching out of the distribution for domestic workers suggests that either some employers at the lowest end are not responding to the law at all, or that employers at the high end are also increasing wages even though they are already compliant with the law, or both.

Figures 1 and 2 underscore the findings in Table 1. Each figure is a kernel densitysmoothed plot of the earnings and wage densities in September 2001 (14 months before the law), March 2002 (8 months before the law) September 2002 (2 months before the law), March 2003 (5 months after the law), September 2003 (10 months after the law) and March (2004) (16 months after the law). The vertical line represents the urban full-time minimum. Pre-law, there is no evidence in the graph that earnings are shifting, despite inflation rates of $6-7 \%$ per annum. ${ }^{32}$ However, each figure shows that the entire (log) earnings and wage distributions shift to the right, in March 2003 with a pronounced mass in the lower tail moving towards the minimum wage line. The shift is even more pronounced by September 2003 and March 2004. We tested for significant differences between these distributions using

\footnotetext{
${ }^{32}$ From the CPIX index provided by Statistics South Africa.
} 
Kolmogorov-Smirnov tests in all pairwise comparisons of each wave. Each of the post-law distributions is significantly different from each of the pre-law distributions. In addition to the prominent shift in wages and earnings after the law, it is clear from these figures that a large fraction of domestic workers continue to earn less than the minimum, and that there is no spike at the minimum that is characteristic of US data for low wage workers (Dinardo, Fortin and Lemieux, 2002). ${ }^{33}$

We consider the shifting of the wage distributions in Figure 1 to be strong evidence that domestic worker wages increased in response to the law, since the shifts are large and line up well with the timing of the law. However, it is still possible that other factors might affect the level of wages in the POST period and confound the effect of the law. For this reason, we would like to know whether wages increased to a larger extent in places where the minimum wage was more binding. Figure 3 provides the basic information we use in our differencein-differences regression. The figure shows the mean (log) hourly wage for domestic workers in each wave, for each of the nine provinces. The black dashed vertical lines demarcate the pre-, cusp and post-periods, while the red dashed horizontal line denotes the urban full-time minimum hourly wage set in November 2002. The graph shows that all but one province had mean hourly wages far below the minimum wage prior to the law. There is no clear evidence of pre-trends in wages that differ between provinces; in a couple of provinces, mean wages look like they increase somewhat in the "cusp" wave of September 2002 (WC, NP and MP). And, although all provinces evidence an increase in mean wages after September 2002, this increase appears to be steeper for provinces falling further below the minimum prior to the law. The figure shows clearly that mean log hourly wage measures are "bunching together" for provinces further away from the minimum in the post-law period.

In Table 2, we statistically test for these changes. The table presents our main differencein-differences results for domestic worker wages. Results from the OLS regression of (1), with robust standard errors clustered at the province level, are shown in columns 1, 2, 5 and 6 . In columns 3, 4, 7 and 8 we present the results from the two-step estimator of Donald and Lang (2007). The first four columns contain results for the full sample of domestic workers and the last four columns restrict the sample by excluding domestic workers in the "cusp" wave of September 2002. We present results without demographic controls (age, education and African indicator) in each odd-numbered column and results from regressions that include the demographic controls in each even-numbered column. All regressions are weighted. ${ }^{34}$

\footnotetext{
${ }^{33}$ We rule out the possibility that these shifts in the wage distribution are driven by compositional changes in the type of domestic workers employed after the law is imposed. In Appendix 2, we use a simple propensity score re-weighting technique (as in Dinardo, Fortin and Lemieux (1996)) to show that the shift in the distribution of observable characteristics (Appendix 2, Figure 1) for workers accounts for a small fraction of the actual shift in wages (Appendix 2, Figure 2).

${ }^{34}$ Results from the unweighted regressions for log hourly wages are presented in Appendix Table 1 for
} 
Across all columns, there is a large, significant increase in wages in the post period, of between 18.9 and $21.7 \%$. This reflects the information in Table 1 and in Figure 3: average wages across all domestic workers increase significantly. ${ }^{35}$ Recall that the pre-law wage gap $\left(W G_{j}\right)$ is defined so that the further below the median wage in a province is from the national minimum, the larger (more positive) value this gap variable takes on. Not surprisingly, in places with larger $W G_{j}$, average wages are significantly lower in the pre-period. However, in the POST period, provinces that were further behind are the ones where the wage response is the largest, as was indicated in Figure 3. The coefficient on $P O S T_{t} * W G_{j}$ is large and positive in each specification and significantly different from zero in both OLS and two-step estimator results, for the sample that excludes September 2002. ${ }^{36}$ For a worker who lives in the province with the largest (demeaned) pre-law wage gap (0.36), the average increase in wages after the law is about $25 \%$ using either the OLS $\left(0.203+0.36^{*} 0.145\right)$ or the two-step $(0.201+0.36 * 0.15)$ results.

In contrast to these large wage effects that appear shortly after the law, hours of work for domestic worker do not exhibit similar significant declines in the POST period. ${ }^{37}$ Table 3 presents results of the form in Table 2, but where the outcome is usual weekly hours of work. Across specifications, the point estimate on the POST indicator is between -0.9 and -1.1 and never statistically significant. Regardless of the method of estimation, the coefficient on $P O S T_{t} * W G_{j}$ is larger and negative, suggesting that hours declined more (between -2.8 and -5.1 hours more) in areas where the initial wage gap was larger. This is between a 7 and $12 \%$ fall in employment on the intensive margin. However, we cannot reject that these estimated changes in hours of work are zero; none of the coefficients on the $P O S T_{t} * W G_{j}$ variable is close to being precisely estimated. Of course, it is possible that measurement error in reports of hours of work undermines our ability to precisely estimate the effect of the law on hours of work. Nevertheless, we find no strong statistical evidence that employers adjusted labor demand on the intensive margin in order to afford the massive increase in wages that are evident in the data.

There is also no evidence that employers adjusted on the extensive margin. If domestic workers lose jobs as a result of the law, we should see different probabilities of low-

comparison.

${ }^{35}$ The wage gap measure is demeaned; so the coefficient on $P O S T_{t}$ can be interpreted as the average change in wages for domestic workers in areas with the average wage gap measure.

${ }^{36}$ The relevant critical values from the $\mathrm{t}$ distribution for a one-tailed test with 5 degrees of freedom are $2.05(\mathrm{p}<0.05$ significance) and $1.47(\mathrm{p}<0.1$ significance). For a two-tailed test, the relevant critical values are $2.57(p<0.05)$ and $2.05(\mathrm{p}<0.1)$. We use the $\mathrm{t}$ distribution because the number of observations in the second step estimation is small.

${ }^{37}$ Sample size changes across tables as more workers report hours of work information than report monthly earnings. Results from the unweighted regressions for weekly hours of work are presented in Appendix Table 2 for comparison. 
skilled African and coloured women being employed as domestic workers POST-law. Table 4 presents difference-in-differences results for the binary outcome "Does the individual work as a domestic worker?". The sample here includes domestic workers and demographically similar women who are working or searching for work. Defining the sample in this way allows for the possibility that domestic workers may switch to other jobs or lose jobs altogether in the POST period. None of the estimated coefficients on the $P O S T_{t}$ or $P O S T_{t} * W G_{j}$ variables is large, or statistically significant, under any specification. ${ }^{38}$

\subsection{Placebo test: difference-in-differences for other workers}

One of the points that differentiates our study from other difference-in-differences approaches to estimating the impact of the minimum wage law is what we are interested in the $P O S T_{t}$ parameter $\alpha_{1}$ as well as the difference-in-differences parameter $\alpha_{3}$. The reason for this is that the minimum wage was set so high in the distribution of domestic worker wages, potentially having effects on workers in all provinces, not just those with the largest pre-law gap between median and minimum wage. We saw from Table 2 that wages increase by about $20 \%$ for all domestic workers, suggesting that this law had a large impact for the average worker. However, we would like to be more confident that this $20 \%$ increase is not solely the result of a large, positive, economy-wide shock to wages occurring at the same time as the minimum wage is introduced.

In Table 5, we present results from our placebo experiment. We implement our main estimating equation in (1) for a group of workers that work in the same areas where our sample of domestic workers are employed (urban areas) but who are not subject to the minimum wage law. These workers are male manufacturing African or coloured workers, who have low levels of education. ${ }^{39}$ The first four columns present OLS and two-step estimator

\footnotetext{
${ }^{38}$ Other types of extensive margin adjustments (of type rather than number of domestic workers) may have altered the composition of domestic workers and contributed to observed earnings shifts. For example, in the POST-period, employers might try harder to select higher quality workers once the law is in place and as a result pay these higher quality domestic workers more. That these changes drive the results we see is ruled out in our propensity-score reweighting exercise in Appendix 2. We check whether the distribution of observable characteristics of domestic workers changes significantly over the period by estimating a probit model of the probability of being a domestic worker in the PRE-period $\left(y_{i}=0\right)$ or the POST period $\left(y_{i}=1\right)$ and plotting the distribution of predicted probabilities for each period in Appendix Figure 1. There is substantial overlap in the propensity scores in the two periods but also a noticeable rightwards shift in the distribution of scores POST-law. To check whether these changes can account for the large shifts in earnings we see after the law, we apply a propensity score weight to the earnings data of observations in the pre-period and graph three kernel density plots of the distribution of earnings reported by workers: the pre-law distribution, the POST distribution and the POST distribution re-weighted for the distribution of characteristics observed in the pre-period (as in Dinardo, Fortin and Lemieux, 1996). Appendix 2 Figure 2 shows that re-weighting in this way does not eliminate the shift in wages from the $P R E$ - to the $P O S T$-period.

${ }^{39}$ Recall from the discussion of the domestic worker sector that the majority of domestic workers are female.
} 
results for log hourly wages, and the final four columns present OLS and two-step estimator results for weekly hours of work. For brevity, we only present the results that exclude individuals appearing in the "cusp" wave of September 2002 (results for the full sample are available upon request).

For the sample of manufacturing workers, wages increase by 9 to $10 \%$ in the POST period, although this change is not significant once we take into account the grouped nature of the data (columns 3 and 4). Moreover, the change in wages for manufacturing workers in high wage gap areas does not seem to be significantly higher in the POST period. These estimates suggest that our difference-in-differences estimates of the wage effects of the law for domestic workers in Table 2 do actually reflect the full impact of the law and not simply differential wage trends in high and low wage gap provinces. They also suggest that we may not be able to attribute the entire $20 \%$ increase in domestic worker wages in the POST period to the new law. If we take the OLS regression results in columns 1 and 2, Table 5, seriously, we are able to reject that the change in mean wages from pre- to post-periods is the same for female domestic workers and male manufacturing workers (the confidence interval for the estimate of $\alpha_{1}$ for domestic workers does not contain 10\%). However, what we learn from combining the results of Tables 2 and 5 is that only about one-half $(10 \%)$ of the wage increase for domestic workers after the law reflects the impact of this law.

Turning to hours of work: these are decreasing somewhat for male manufacturing workers in the post period, and by similar magnitudes - although these changes are not significant in our two-step results. Hours of work increase in the post period in high wage gap areas, although these are again, not significantly different from zero once we take into account the grouped nature of the error term in (1) in the presence of a small number of groups. Overall then, the evidence from the sample of male manufacturing workers does not point to differential trends in wages or hours of work across high and low wage gap provinces; nor does it seem that the entirety of the $20 \%$ increase in domestic worker wages after the law can be accounted for by contemporaneous shocks that these manufacturing workers are also experiencing. ${ }^{40}$

\subsection{Testing for partial compliance}

In this section, we provide suggestive evidence that some of the wage increases that occur after the law are only in partial compliance with the minimum. This is important to show, because it gives us some sense of how this informal labor market operates. It suggests that the effects of the law are not simply driven by a subset of employer-types who are law-abiding;

\footnotetext{
${ }^{40}$ Tests for the differences in coefficients across domestic worker and manufacturing worker samples are implemented in a difference-in-difference-in-differences specification. Estimates not shown for brevity.
} 
rather that some employers are voluntarily choosing whether and how much to comply with the law.

Table 6 presents results from the ordered probit model we estimated for an outcome variable that classifies a worker's wage into a range below, near or above the minimum in each wave. Since the choice of cut-offs for being "near" the minimum is arbitrary, we perform this test defining "near" in two different ways: a wage $10 \%$ or less than the minimum and a wage $20 \%$ or less than the minimum. Recalling from the discussion above and as described in Appendix 1, the idea of the test is that if the probability of a worker reporting a wage in the non-compliant bin falls by more than the probability of a worker earning a wage in the compliant bin rises, then some workers are earning more than they were before, but not enough more to bring them into compliance with the law. This test is informative as long as there are no large employment responses to the law, which we showed above in Table 4. The first three columns of Table 6 present results for the specification that includes only a $P O S T_{t}$ indicator and a constant (in column (1)) and other demographic control variables including age, education and race of worker (in columns (2) and (3)). Results presented are the marginal effects from the ordered probit.

To interpret results, consider the coefficients in column (1). In the POST period, the probability of a worker reporting hourly wages below $10 \%$ below the minimum falls by $14.9 \%$. In the same period, the probability of earning above the minimum increased by only $14.2 \%$. This means that a significant $0.7 \%$ of the reduction in mass at the lower end of the distribution shifted into the narrow band near the minimum. Adding controls does not change this result substantially (column (2)), although changing the definition of "near" compliant does result in a larger increase in the fraction of domestic workers earning wages near the minimum (column (3)): 1.2\%. The coefficient on $P O S T_{t}$ is significantly different from zero, suggesting that some of the shift in wages is indeed only in partial compliance with the law.

The last three columns in Table 5 present marginal effects from the ordered probit model of domestic worker wage categories that includes controls for $P O S T_{t}$, the log wage gap in the province before the law, the interaction of these two variables, a constant (in column (4)) and age, education and race (in columns (5) and (6)). The only marginal effects we show here are the coefficients on the $P O S T_{t}$ term (top three rows) and the coefficients on the interaction of $P O S T_{t} * W G_{j}$ (bottom three rows). The message from these results is the same: between $0.8 \%$ and $1 \%$ of domestic workers shifted from the lower part of the wage distribution towards (but not up to) the new minimum. This partial response to the law does not appear to be significantly larger in the provinces where the minimum wage had the most bite. The change in fraction with near-compliant wages in high wage gap 
provinces is between $0.4 \%$ and $0.5 \%$ larger than in provinces with the mean wage gap but these differences are not statistically different from zero. ${ }^{41}$

The results of this test indicate partial compliance from the lower part of the wage distribution, in all provinces. The evidence on increasing dispersion in wages and earnings in Table 1 and the increases in mean log hourly wages for domestic workers in the Western Cape (Figure 3) - the only province where the mean wage was initial above the minimumpoint toward an employer response at levels much higher in the distribution. Together, these pieces of evidence suggest that some employers are responding to the law in ways different to those predicted by conventional compliance models. In the next section, we present a final test that tries to rule out the possibility that employer responses are driven by a desire to avoid penalties associated with non-compliance.

\subsection{Testing for compliance related to probability of audit}

To learn more about how much employer behavior may be driven by the threat of external sanction, we investigate the responsiveness of wages to the presence of a local LC. Having a LC nearby should increase the actual probability of audit as well as employer beliefs about their likelihood of being monitored. While this is not the only aspect of a local labor market that could increase the likelihood of being caught for non-compliance, it is a plausible feature that distinguishes markets and it is feasible to obtain data on these offices. Having a nearby LC represents a lower cost of complaint for the domestic worker. We tracked down the physical addresses of these LCs and matched each one to a unique magisterial district in the LFS, a geographic unit that is more disaggregated than the province. Since the LCs were primarily established to serve formal sector workers in the rest of the economy, it is unlikely that their location is endogenous to the prevalence of domestic worker employers or to the presence of non-compliant employers of domestic workers; however, the LCs are likely to be over-represented in areas with more economic activity in the formal sector. Across all waves, $75 \%$ of domestic workers live in magisterial districts where there is at least one LC.

In Table 7, we estimate wage regressions of the form in Table 2, now including a control for whether the domestic worker lives in a magisterial district with an LC, the interaction of this indicator with $P O S T_{t}$, with $W G_{j}$ and the triple interaction $P O S T_{t}{ }^{*} W G_{j}{ }^{*} L C_{i j t}$. We estimate equation (1) again using OLS (and clustered standard errors) as well as using the two-step estimator. Interestingly, the OLS results indicate that domestic worker wages are about $11-12 \%$ higher in areas that have an LC (in columns (1), (2), (5), (6)) and that LCs tend to offset the effect of working in a province where the median wage in the pre-period

\footnotetext{
${ }^{41}$ We estimate ordered probits for log earnings and find similar evidence of partial compliance behavior. Results available upon request.
} 
is below the minimum (coefficient on $L C * W G$ ). However, neither of these differences are evident once we estimate the model using the two-step procedure. Furthermore, there seems to be no evidence that having an LC in one's local labor market increases the impact of the minimum wage for domestic workers; employers who raise wages are not doing so differentially in areas where the likelihood of being caught for non-compliance is higher. Although it is never possible to precisely estimate the coefficient on $L C * W G * P O S T$, the coefficient on this triple-difference term is negative, pointing in the "wrong direction" for the mechanism that has employers responding more in areas with a higher probability of audit.

\subsection{Contract coverage}

Historically, remuneration for domestic workers has included a combination of cash and inkind benefits. It is therefore possible that the entire shift in the wage distribution could have been facilitated by a change in the structure of remuneration: increases in wages in response to the law may have been offset by decreases in in-kind payments. Ideally, we would like to know whether the minimum wage law and all of its components had any real effects on conditions of employment for domestic workers. The minimum wage determination also mandated formal labor contracts in the domestic work sector; hence, we consider the impact of the law on this important non-pecuniary aspect of the work relationship.

Figure 4 shows the basic result for contract coverage: the fraction of domestic workers covered by a formal job contract is below 30\% in all provinces up until March 2003. Then, this fraction increases substantially, across all provinces, in September 2003 and March 2004. In Table 8, we present the difference-in-differences comparisons for the outcome "Does the worker have a written contract of employment?" Across all specifications, regardless of whether the "cusp" wave is omitted or not, there is a 16-20 percentage point increase in the fraction of domestic workers covered by an employment contract. Considering that the baseline contract coverage rate was about $10 \%$, this more than doubling of the rate of coverage in the year after the law is enacted is remarkable. In addition, the evidence in this table suggests that the average domestic worker benefited from these changes, regardless of whether or not they worked in a province paying far below the minimum. Although it is possible that only the employers already paying compliant wages are the ones establishing formal wage contracts with their employees, at the aggregate level, Figure 4 suggests that increases in contract coverage are not primarily driven by provinces where mean wages were already in compliance with the law (i.e. the Western Cape). In fact, these differences do not appear to be related to the intensity of the new wage floor across provinces (this is evident in both the Figure 4 and Table 8 results). 
We view this last set of results as particularly important. Contracts of employment include provisions regarding pay, overtime pay, pension and other benefits, vacation time and rules about fair termination of employment. What we are seeing in the LFS is that the employment relationship for many domestic workers became more formal immediately after the law, regardless of their position in the wage distribution. These workers gained protections that they previously did not have access to, and so the new regulation appears to have initiated the formalization of the industry. This process could have far-reaching consequences for the nature of domestic work in South Africa.

\section{Discussion and conclusions}

The introduction of a new minimum wage law in a previously unregulated informal market presents a unique opportunity to examine important issues around responses to legal wage floors. It also allows us a window into how informal labor markets operate and the conditions under which they might formalize.

Although conditions in and characteristics of the domestic worker industry in South Africa were stable before the introduction of a minimum wage, wages in this sector rose significantly and substantially - at least 10\% compared with other workers - POST-law. When we consider the difference-in-differences results, it is clear that domestic workers who work in areas where the pre-law median wage is below the minimum (i.e. where the new law has more "bite") experienced even larger increases in wages in the POST-period. Despite the absence of full compliance and a sharp wage spike at the minimum, we find evidence of a strong wage response to the law, and little statistical evidence that the law had a negative effect on work on the intensive or extensive margin. The main purpose of our paper has been to document these changes and to provide evidence that labor market regulation in an informal sector of considerable importance can have real impact, even without monitoring or enforcement.

Given that issues of compliance are not often at the center of empirical work on minimum wages $^{42}$, it is worthwhile considering how our results should be interpreted. One possible reason that the law had an effect is that some fraction of employers erroneously believed that the government was going to enforce the new minimum and penalize non-compliers. A difficulty with this explanation is that it cannot account for wage or earnings increases for domestic workers already paid more than the minimum before the law. Although we do not have a panel data set of workers to test this directly, the fact that the wage and

\footnotetext{
${ }^{42}$ For comprehensive reviews of the minimum wage literature, see Brown (1999), Card and Krueger (1997) and Neumark and Wascher (1995, 2007).
} 
earnings distribution fanned out (the variance increased) rather than compressing after the law suggests that some employers increased wages in excess of the minimum, despite already being compliant with the law.

A second reason that an unenforced law may have been effective relates to models of fairness in wage-setting. A theoretical literature in labor economics posits that the notion of a fair wage is important in incentivizing workers to provide high effort in tasks for which effort is unobservable (Akerlof, 1982, 1984 and Akerlof and Yellen, 1988). These models are difficult to test empirically, since defining and measuring a fair wage, or a reference wage, is tricky in practice. ${ }^{43}$ Experimental studies have separately established the importance of gift exchange and fairness intentions in employer-employee relationships. ${ }^{44}$ In the case of the domestic worker industry in South Africa, it is plausible that the announcement of a wage floor defined, or re-defined, what the fair wage was and set in motion voluntary employer responses, even though the two traditional channels for encouraging compliance- enforcement and penalties- were closed off. ${ }^{45}$ What we take from our analysis is that in the initial stages of labor market formalization, governments may need to accept partial compliance with new legislation in order to bring about real changes in outcomes without significant disemployment. ${ }^{46}$ Even without enforcement, such legislation can move the market towards a more formal setting, if, for example, it increases contract coverage, as in the South African case.

We emphasize that our conclusions are valid for the domestic worker industry, which is one example of an informal sector. The dynamics of the employment relationship between a single employer and a single employee no doubt condition the response to the law and so may only be relevant in some types of informal enterprizes. However, this characterization of the informal sector may not be too far from a description of the typical small-scale firm that generates much informal sector employment in developing countries. ${ }^{47}$ Also, our analysis is

\footnotetext{
${ }^{43}$ Mas (2006) is an exception.

${ }^{44}$ See for example Brandts and Charness (2004), who show that a minimum wage may undermine the efficiencies that gift-exchange can achieve, Falk et al (2000) discuss how fairness intentions matter for behavior and Fehr et al (1997) model how reciprocity in response to fair behavior expands the set of enforceable contracts that can be sustained in an economy. Konow (2003) reviews the large body of experimental evidence on fairness. Falk, Fehr and Zehnder (2005) provide a model and experimental evidence that the announcement of a minimum wage raises workers' reservation wages in a persistent way. Reservation wages remain high even after the wage floor is removed, suggesting that policy interventions may have direct and indirect effects on behavior by altering the meaning of a fair transaction and by creating 'entitlement' effects.

${ }^{45}$ Rebitzer and Taylor (1995) present a theoretical model of a labor market in which employment increases when the minimum wage increases, as a result of an efficiency wage. However, they assume compliance with the law in their model. They focus on showing how an efficiency wage model can predict an increase in labor demand following a minimum wage change.

${ }^{46}$ See Basu, Chau and Kanbur (2007) for a theoretical discussion of why non-compliance with a minimum wage could be acceptable.

${ }^{47}$ Banerjee and Duflo (2006)) show that small-scale firms and entrepreneurial activities are an important
} 
only relevant for the short-run effects of a new minimum wage policy: while we find clear effects in the 16 months after the law, as employers face annual increases in this minimum (often above inflation in the case of South Africa) and as workers sort across space in response to these new protections, the wage, earnings and employment effects of the policy may change as the sector itself becomes more formal over time. For example, employers may decide to contract child-care out to day-care centers which could have feedback effects on equilibrium wages, earnings, hours of work and number of jobs for domestic workers. We leave questions about the longer-term effects of formalizing the domestic worker market for future research.

source of income for the poor. 


\section{References}

Akerlof, George, "Labor contracts as partial gift exchange," Quarterly Journal of Economics, 1982, 97 (4), 543-569.

, "Gift exchange and efficiency-wage theory: Four views," American Economic Review, 1984, 74 (2), 79-83.

and Janet Yellen, "Fairness and unemployment," American Economic Review, 1988, $78(2), 44-49$.

Ashenfelter, Orley and Richard Smith, "Compliance with the minimum wage law," Journal of Political Economy, April 1979, 2, 333-350.

Banerjee, Abhijit and Esther Duflo, "The economic lives of the poor," October 2006. Mimeo, MIT.

Basu, Arnab K., Nancy H. Chau, and Ravi Kanbur, "Turning a blind eye: Costly enforcement, credible commitment and minimum wage laws," August 2007. IZA Discussion Paper No. 2998.

Bell, Linda A., "The impact of minimum wages in Mexico and Colombia," Journal of Labor Economics, 1997, (15: 2).

Bertrand, Marianne, Esther Duflo, and Sendhil Mullainathan, "How much should we trust difference-in-differences estimates?," Quarterly Journal of Economics, 2004, $119(1), 249-275$.

Besley, Timothy and Robin Burgess, "Can labor regulation hinder economic performance? Evidence from India," Quarterly Journal of Economics, 2004.

Bloom, David and Georges Grenier, "Models of Firm Behavior under Minimum Wage Legislation," NBER Working Paper, 1986, (1877).

Brandts, Jordi and Gary Charness, "Do labour market conditions affect gift exchange? Some experimental evidence," 2004. Universitat Pompeu Fabra Working Paper No. 491.

Branson, Nicola, "Re-weighting the OHS and LFS National Household Survey Data to create a consistent series over time: A Cross Entropy Estimation Approach," 2009. SALDRU/DataFirst Working Paper Series number 38.

Brown, Charles, "Minimum wage laws: Are they overrated?," Journal of Economic Perspectives, 1988, 2 (3).

, Handbook of Labor Economics, Vol. 3, Elsevier Science, 1999.

Budlender, D., E. Kalula, B. Letsoela, B. Ntshalintshali, and Z. Rustomjee, "Recommendations of the Employment Conditions Commission on the Investigation into the Domestic Worker Sector," Technical Report, South African Department of Labour 2002. 
Card, David and Alan Krueger, Myth and Measurement: The New Economics of the Minimum Wage, Princeton University Press, 1997.

Chang, Yangming, "Noncompliance behavior of risk averse firms under the minimum wage law," Public Finance Quarterly, 1992, 20 (3), 390-402.

and Isaac Ehrlich, "On the economics of compliance with the minimum wage law," Journal of Political Economy, 1985, 93 (1), 84-91.

Cock, Jacklyn, Maids and madams : domestic workers under apartheid, London : Womens Press, 1989.

Cortes, Kalena, "Wage Effects on Immigrants from an Increase in the Minimum Wage Rate: An Analysis by Immigrant Industry Concentration," Working Paper, IZA Discussion Paper No. 10642004.

Cortes, Patricia and Jessica Pan, "Outsourcing household production: Foreign domestic helpers and native labor supply in Hong Kong," 2009. Mimeo, Chicago Booth School.

DiNardo, John, Nicole Fortin, and Thomas Lemieux, "Labor Market Institutions and the Distribution of Wages, 1973-1992 : A Semiparametric Analysis," Econometrica, September 1996, 64, 1001-1044.

Donald, Stephen G. and Kevin Lang, "Inference with difference-in-differences and other panel data," Review of Economics and Statistics, 2007, 89 (2), 221-233.

Falk, Armin, Ernst Fehr, and Christian Zehnder, "The behavioral effects of the minimum wage," June 2005. IZA Discussion Paper No. 1625.

, and Urs Fischbacher, "Testing Theories of Fairness-Intentions Matter," 2000. University of Zurich.

Fehr, Ernst, Simon Gachter, and Georg Kirschteiger, "Reciprocity as a contract enforcement device: experimental evidence," Econometrica, 1997, 65 (4).

Gindling, T. H. and Katherine Terrell, "Legal minimum wages and the wages of formal and informal sector workers in Costa Rica," February 2004. IZA Discussion Paper No. 1018.

Grenier, Georges, "On compliance with the minimum wage law," Journal of Political Economy, 1982, 90 (1), 184-187.

Hertz, Tom, "Have minimum wages benefited South Africa's domestic service workers?," 2006. Working paper, Department of Economics, American University.

Konow, James, "Which is the fairest one of all? A positive analysis of justice theories," Journal of Economic Literature, 2003, 41 (4).

Kremer, Michael and Stanley Watt, "The globalization of household production," September 2006. Mimeo, Harvard University. 
Lee, David, "Wage inequality in the United States during the 1980s: Rising dispersion or falling minimum wage?," Quarterly Journal of Economics, August 1999, 114 (3), 977-1023.

Lemos, Sara, "Minimum wage effects in a developing country," Labour Economics, 2009, 16 .

Lott, John R. and Russell D. Roberts, "The Expected Penalty for committing a crime: An Analysis of Minimum Wage Violations," Journal of Human Resources, 1995, 30 (2), 397-408.

Louw, Megan and Servaas van der Berg, "Labour trends observed in South Africa: 1995-2002," Technical Report, The World Bank and University of Stellenbosch 2004. DIFID-WB Collaboration on Knowledge and Skills in the New Economy.

Lustig, Nora and Daniel McLeod, Labor markets in Latin America, Brookings Institution Press, 1997.

Maloney, W. and J. Menendez, Law and Employment: Lessons from Latin America and the Caribbean, NBER and University of Chicago, 2004.

Mas, Alex, "Pay, reference points and policy performance," Quarterly Journal of Economics, August 2006.

Neumark, David and William Wascher, "Minimum Wage Effects on School and Work Transitions of Teenagers," American Economic Review Papers and Proceedings, May $1995,85(2), 244-49$.

_ and _ , "Minimum wages and employment," January 2007. IZA Discussion Paper No. 2570.

Rebitzer, James B. and Lowell J. Taylor, "The consequences of minimum wage laws: Some new theoretical ideas," Journal of Public Economics, 1995, 56, 245-255.

Rubinow, I. M., "The problem of domestic service," Journal of Political Economy, 1906, $14: 8,502-519$.

South African Department of Labor, "Labor Relations Act 1995," Technical Report, South African Government 1995.

Squire, Lyn and Sethaput Suthiwart-Narueput, "The impact of labor market regulations," World Bank Research Observer, 1997, 11 (1), 119-143.

Statistics South Africa, "Labor Force Surveys Waves 4-8," Technical Report, South African Government 2000-2003.

—_ "Income and Expenditure Surveys 2000 and 2005," Technical Report, South African Government 2000, 2005.

Thiess, Clifford F., "The first minimum wage laws," CATO Journal, 1991, Winter (10). 
Weil, David, "Public Enforcement/Private Monitoring: Evaluating a new approach to regulating the minimum wage," Industrial and Labor Relations Review, January 2005, 58. 
Figure 1: Distribution of log hourly wages for urban domestic workers

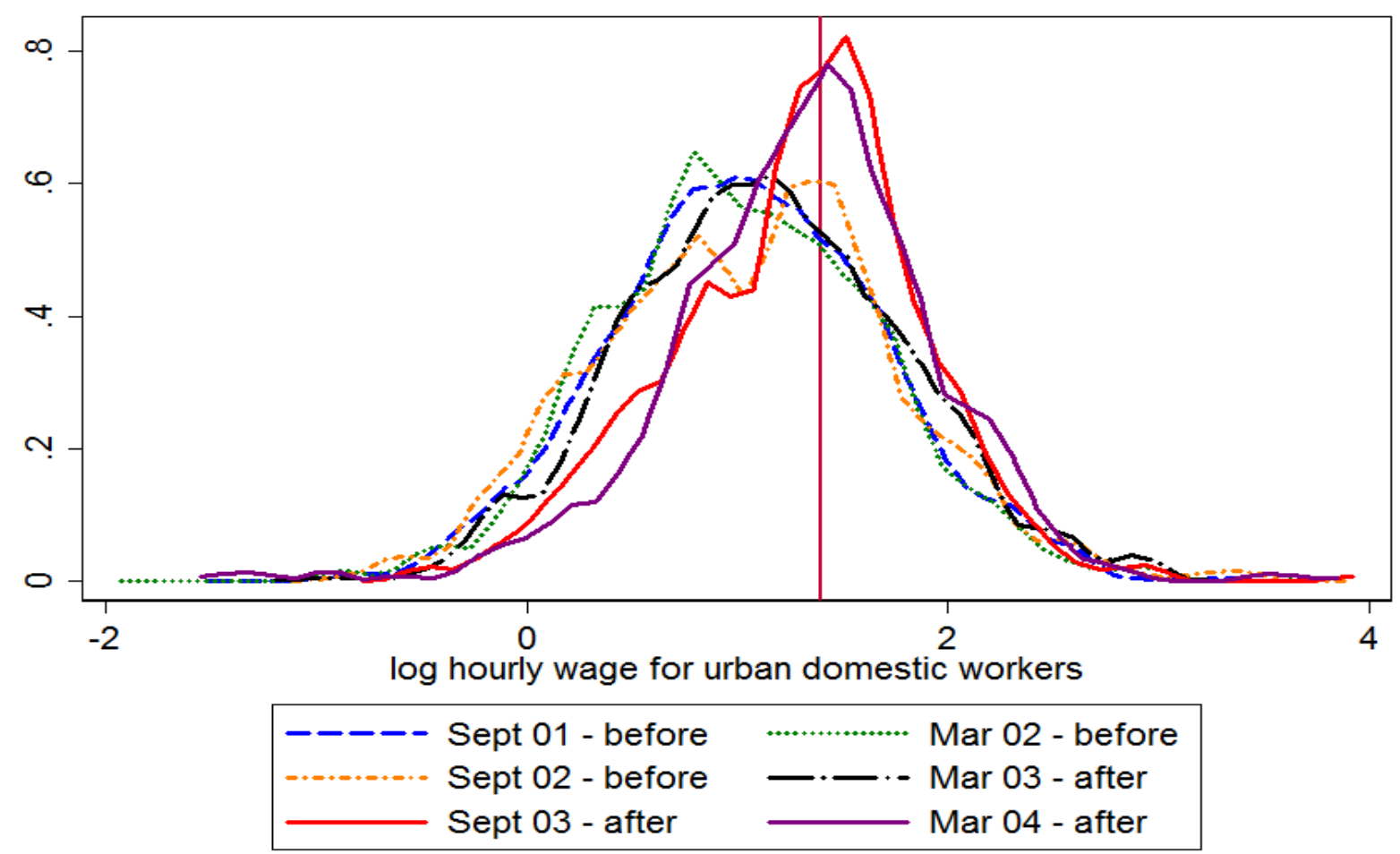

Figure 2: Distribution of log monthly earnings for urban domestic workers

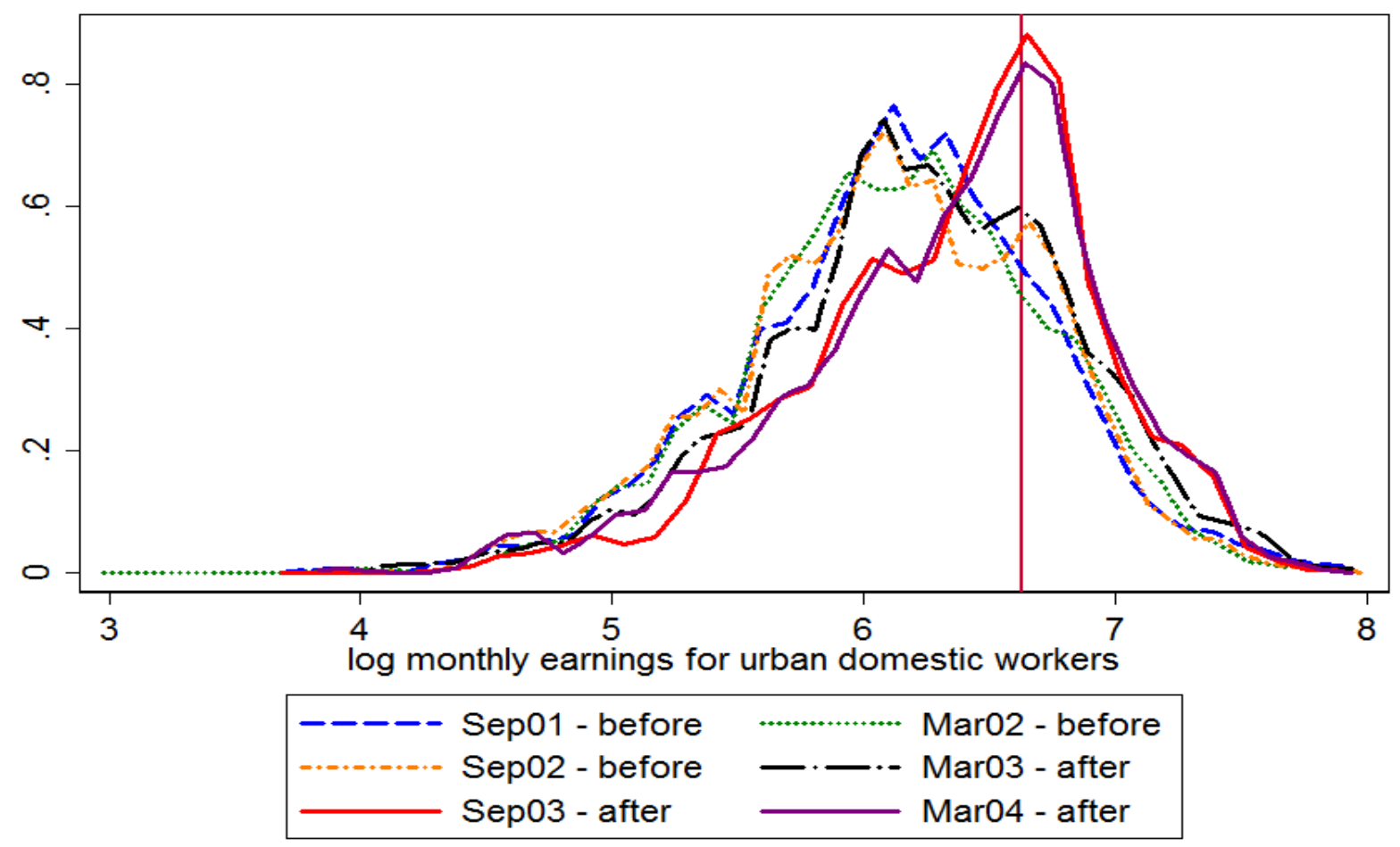

Kernel density plots of log hourly wages (bandwidth 0.02) and log monthly earnings (bandwidth 0.08). Data are from South African Labor Force Surveys (March 2001-March 2004). The vertical line is at the level of the full-time minimum wage (monthly income) for urban domestic workers. Each wave of data contains between 996 and 1,260 observations. Kolmogorov-Smirnov tests of equality of distributions reject at the $5 \%$ level for each pairwise comparison of waves in the before and after periods. 
Figure 3: Mean hourly domestic worker wages by province over time

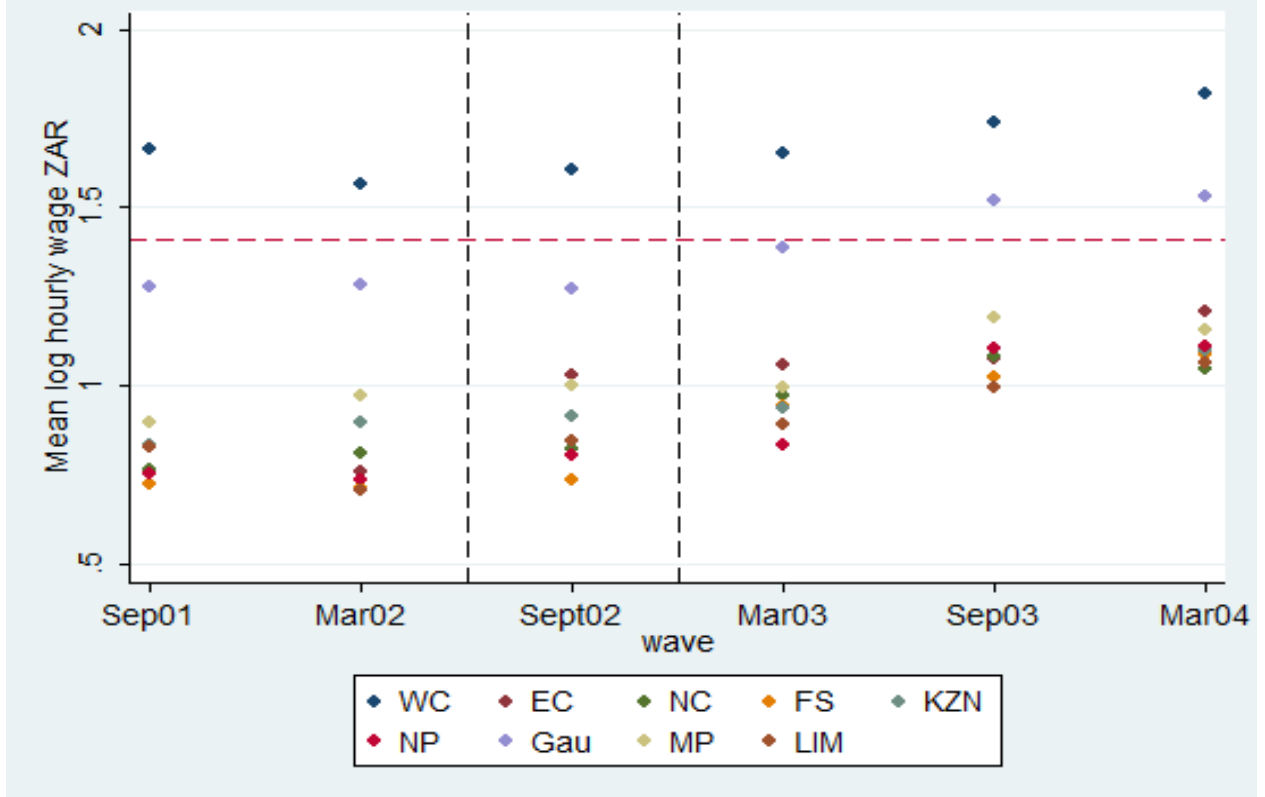

Each dot represents a province-wave level mean hourly wage for domestic workers, for waves before and after the law. The black vertical dashed lines demarcate the period before (to the left) and the period after (to the right) the law, with the "cusp" period falling between these lines. The red horizontal dashed line represents the urban full-time minimum wage (ZAR4.1) established in November 2002. All data are from the South African Labor Force Surveys (March 2001-March 2004) and means are weighted. Provinces are: Western Cape (WC), Eastern Cape (EC), Northern Cape (NC), Free State (FS), Kwazulu-Natal (KZN), Northern Province (NP), Gauteng (Gau), Mpumalanga (MP) and Limpopo (LIM).

Figure 4: Fraction of domestic workers with a formal job contract

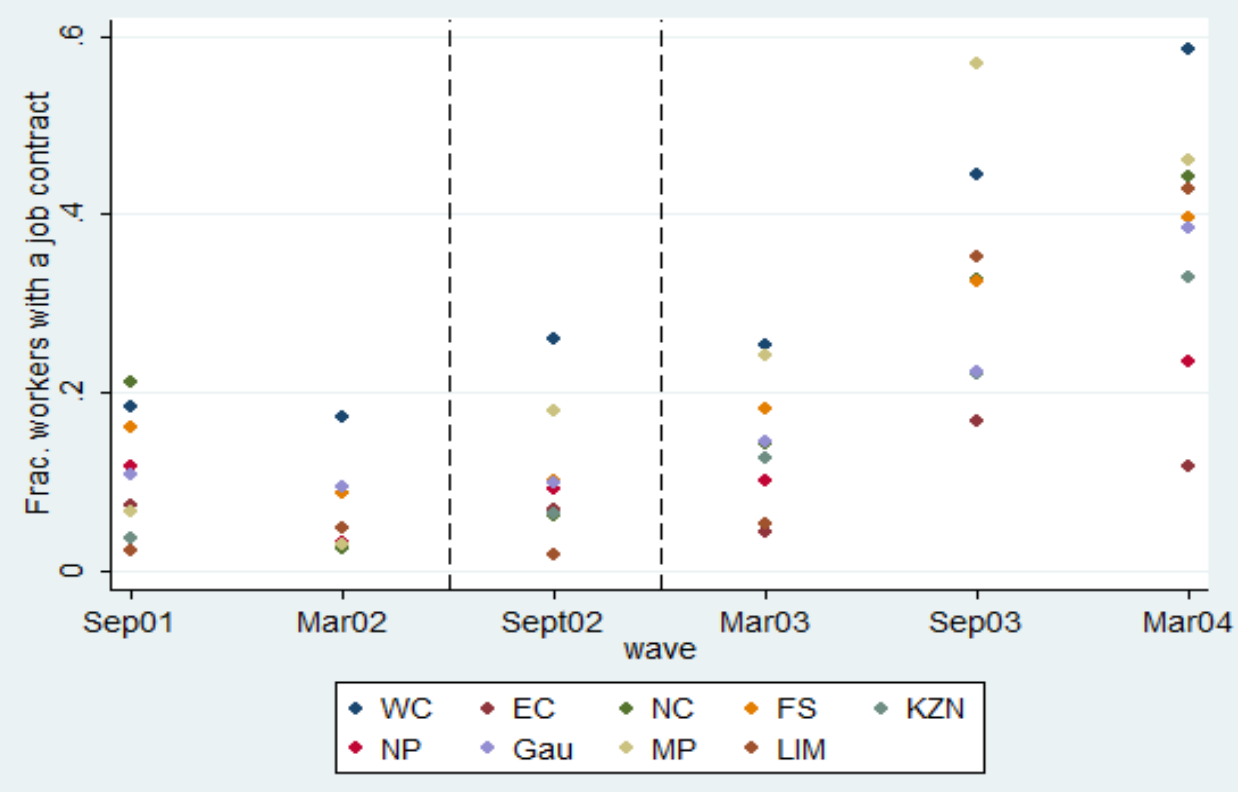

Each dot represents a province-wave level fraction of domestic workers with a formal job contract, for waves before and after the law. The black vertical dashed lines demarcate the period before (to the left) and the period after (to the right) the law, with the "cusp" period falling between these lines. All data are from the South African Labor Force Surveys (March 2001-March 2004) and means are weighted. Provinces are: Western Cape (WC), Eastern Cape (EC), Northern Cape (NC), Free State (FS), Kwazulu-Natal (KZN), Northern Province (NP), Gauteng (Gau), Mpumalanga (Mp) and Limpopo (Lim). 
Table 1: Mean characteristics of domestic workers LFS 2001-2004

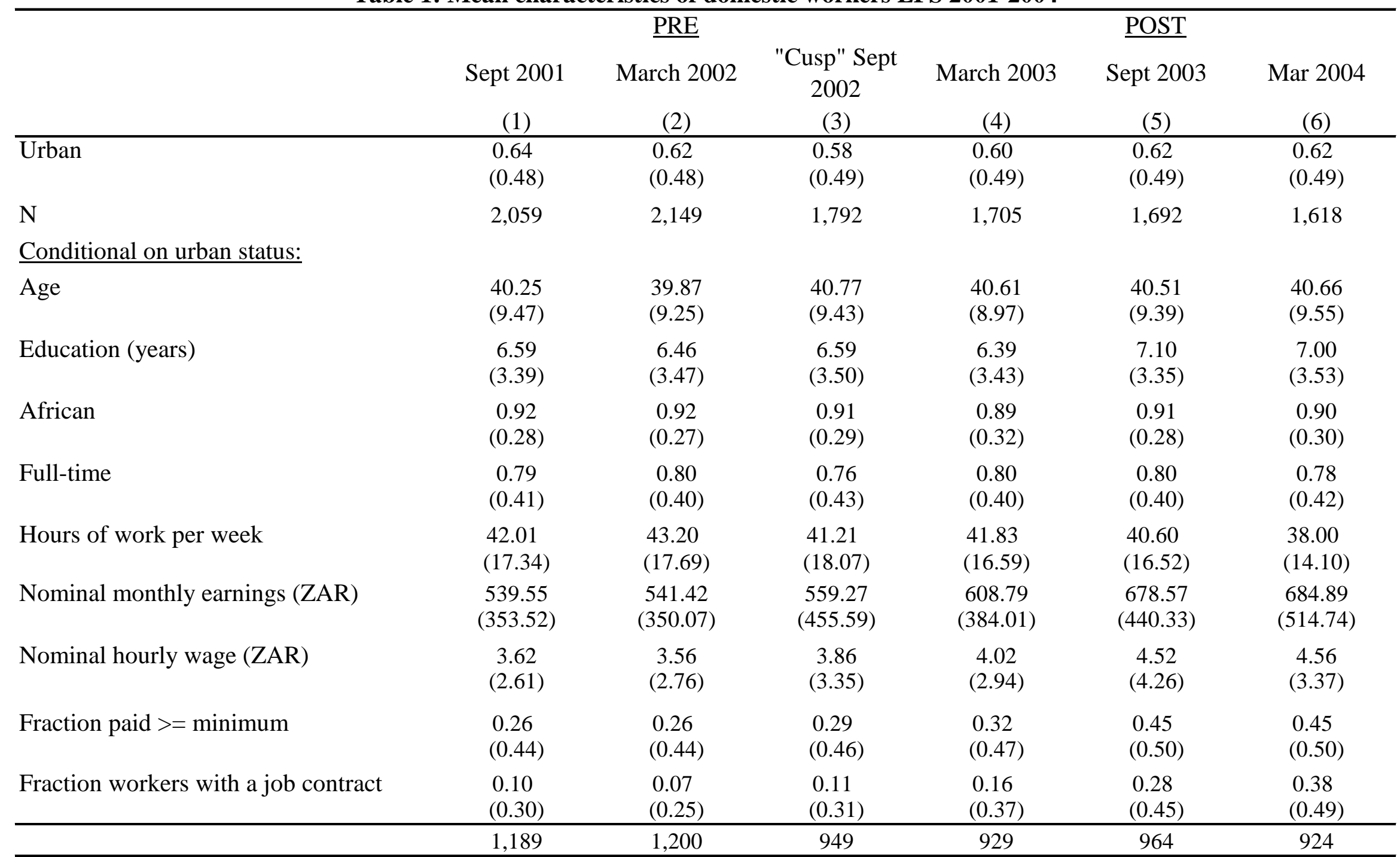

Data are from South African Labor Force Surveys (LFS 2001-2004). All data are self-reported by domestic workers and statistics are weighted.

Sample in the lower panel includes female African and coloured domestic workers aged 20-59 inclusive, each of whom have all information on the included variables and who live in urban areas.

A full-time worker is someone who reports at least 27 hours of work per week. The lowest wage provinces are the Northern province and the Eastern Cape: these provinces have the two lowest median hourly wages for domestic workers in the pre-period (September 2001 and March 2002 ). 
Table 2: Log hourly wages of domestic workers: Difference-in-differences

\begin{tabular}{|c|c|c|c|c|c|c|c|c|}
\hline & \multicolumn{4}{|c|}{ All waves } & \multicolumn{4}{|c|}{ Excluding "cusp" wave } \\
\hline & \multicolumn{2}{|c|}{$\underline{\mathrm{OLS}}$} & \multicolumn{2}{|c|}{$\underline{\text { Two-step estimator }}$} & \multicolumn{2}{|c|}{$\underline{\mathrm{OLS}}$} & \multicolumn{2}{|c|}{ Two-step estimator } \\
\hline & $(1)$ & $(2)$ & (3) & $(4)$ & (5) & (6) & (7) & $(8)$ \\
\hline POST & $\begin{array}{c}0.202 * * * \\
(0.02)\end{array}$ & $\begin{array}{c}0.193 * * * \\
(0.02)\end{array}$ & $\begin{array}{c}0.201 * * * \\
(0.03)\end{array}$ & $\begin{array}{c}0.189 * * * \\
(0.03)\end{array}$ & $\begin{array}{c}0.215 * * * \\
(0.02)\end{array}$ & $\begin{array}{c}0.203 * * * \\
(0.02)\end{array}$ & $\begin{array}{c}0.217 * * * \\
(0.03)\end{array}$ & $\begin{array}{c}0.202 * * * \\
(0.03)\end{array}$ \\
\hline Pre-law wage gap (WG) & $\begin{array}{c}-0.858 * * * \\
(0.04)\end{array}$ & $\begin{array}{c}-0.820 * * * \\
(0.05)\end{array}$ & $\begin{array}{c}-0.829 * * * \\
(0.05)\end{array}$ & $\begin{array}{c}-0.792 * * * \\
(0.04)\end{array}$ & $\begin{array}{c}-0.902 * * * \\
(0.04)\end{array}$ & $\begin{array}{c}-0.862 * * * \\
(0.04)\end{array}$ & $\begin{array}{c}-0.868 * * * \\
(0.04)\end{array}$ & $\begin{array}{c}-0.827 * * * \\
(0.04)\end{array}$ \\
\hline $\begin{array}{l}\text { Controls for age, education, } \\
\text { African? }\end{array}$ & $\mathrm{N}$ & $\mathrm{Y}$ & $\mathrm{N}$ & $\mathrm{Y}$ & $\mathrm{N}$ & $\mathrm{Y}$ & $\mathrm{N}$ & $\mathrm{N}$ \\
\hline $\mathrm{N}$ & 6,154 & 6,154 & 18 & 18 & 5,205 & 5,205 & 18 & 18 \\
\hline \multicolumn{9}{|c|}{ 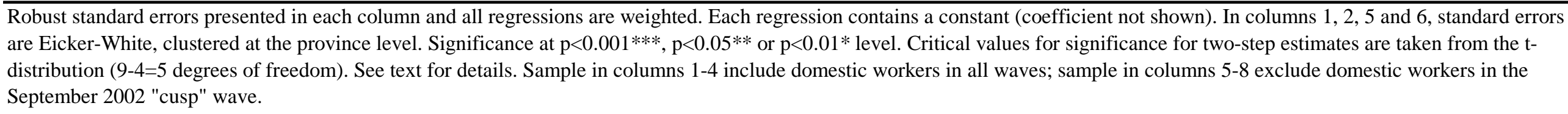 } \\
\hline \multicolumn{9}{|c|}{ Outcome is the log of hourly wages, computed by taking monthly earnings and dividing by usual number of hours worked per week. } \\
\hline
\end{tabular}


Table 3: Usual weekly hours of work of domestic workers: Difference-in-differences

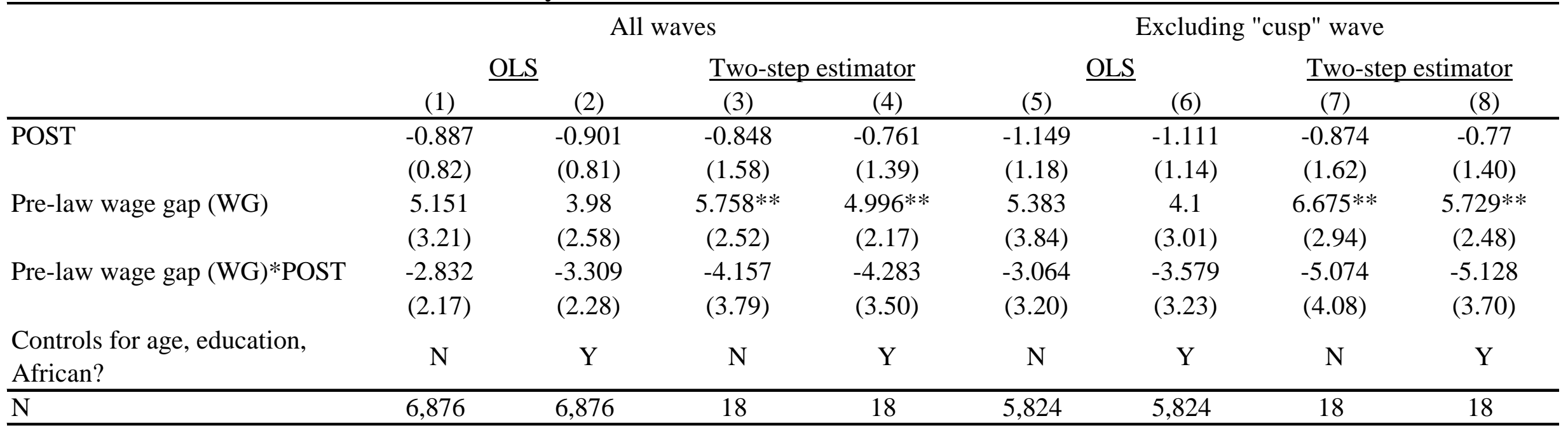

Robust standard errors presented in each column and all regressions are weighted. Each regression contains a constant (coefficient not shown). In columns 1, 2, 5 and 6, standard errors are Eicker-White, clustered at the province level. Significance at $\mathrm{p}<0.001^{* * *}, \mathrm{p}<0.05^{* *}$ or $\mathrm{p}<0.01^{*}$ level. Critical values for significance for two-step estimates are taken from the t-distribution (9-4=5 degrees of freedom). See text for details. Sample in columns 1-4 include domestic workers in all waves; sample in columns 58 exclude domestic workers in the September 2002 "cusp" wave.

Outcome is usual number of hours worked per week.

POST=1 in March 2003, September 2003 and March 2004; otherwise zero.

Pre-law wage gap is the province-level difference in the $\log ($ median wage)-log(4.1), where 4.1 is the urban full-time minimum wage introduced in November 2002 and median wage is the median wage of domestic workers in each province across all of the pre-waves (September 2001 and March 2002). 
Table 4: Probability of working as a domestic worker: Difference-in-differences

\begin{tabular}{|c|c|c|c|c|c|c|c|c|}
\hline & \multicolumn{4}{|c|}{ All waves } & \multicolumn{4}{|c|}{ Excluding "cusp" wave } \\
\hline & \multicolumn{2}{|c|}{$\underline{\text { OLS }}$} & \multicolumn{2}{|c|}{$\underline{\text { Two-step estimator }}$} & \multicolumn{2}{|c|}{$\underline{\text { OLS }}$} & \multicolumn{2}{|c|}{ Two-step estimator } \\
\hline & (1) & (2) & (3) & (4) & (5) & (6) & (7) & (8) \\
\hline \multirow{2}{*}{$\overline{\mathrm{POST}}$} & -0.004 & 0.003 & -0.012 & -0.005 & -0.010 & -0.002 & -0.014 & -0.007 \\
\hline & $(0.01)$ & $(0.01)$ & $(0.01)$ & $(0.01)$ & $(0.01)$ & $(0.01)$ & $(0.01)$ & $(0.01)$ \\
\hline \multirow[t]{2}{*}{ Pre-law wage gap (WG) } & $0.0409 * * *$ & -0.014 & $0.0594 * *$ & -0.008 & $0.0386 * *$ & $-0.0173 * *$ & $0.0610^{* *}$ & -0.007 \\
\hline & $(0.01)$ & $(0.01)$ & $(0.02)$ & $(0.02)$ & $(0.02)$ & $(0.01)$ & $(0.02)$ & $(0.02)$ \\
\hline \multirow[t]{2}{*}{ Pre-law wage gap (WG)*POST } & -0.004 & 0.002 & -0.024 & -0.017 & -0.002 & 0.004 & -0.025 & -0.018 \\
\hline & $(0.02)$ & $(0.02)$ & $(0.03)$ & $(0.03)$ & $(0.03)$ & $(0.03)$ & $(0.03)$ & $(0.03)$ \\
\hline $\begin{array}{l}\text { Controls for age, education, } \\
\text { African? }\end{array}$ & $\mathrm{N}$ & $\mathrm{Y}$ & $\mathrm{N}$ & $\mathrm{Y}$ & $\mathrm{N}$ & $\mathrm{Y}$ & $\mathrm{N}$ & Y \\
\hline $\mathrm{N}$ & 52,742 & 52,742 & 18 & 18 & 44,005 & 44,005 & 18 & 18 \\
\hline
\end{tabular}

Robust standard errors presented in each column and all regressions are weighted. Each regression contains a constant (coefficient not shown). In columns 1, 2, 5 and 6 , standard errors are Eicker-White standard errors, clustered at the province level. Significance at p $<0.001 * * *$, p $<0.05^{* *}$ or $\mathrm{p}<0.01 *$ level. Critical values for significance of two-step estimates are taken from the t-distribution (9-4=5 degrees of freedom). See text for details. Sample in columns 1-4 include employed or unemployed women aged 20-59 (searching unemployed) who have no more than high school; sample in columns 5-8 excludes all of the individuals in this group who appear in the September 2002 "cusp" wave.

Outcome is whether the individual is employed as a domestic worker (1) or not (0).

POST=1 in March 2003, September 2003 and March 2004; otherwise zero.

Pre-law wage gap is the province-level difference in the log(median wage)-log(4.1), where 4.1 is the urban full-time minimum wage introduced in November 2002 and median wage is the median wage of domestic workers in each province across all of the pre-waves (September 2001 and March 2002 ). 
Table 5 Placebo test: Difference-in-differences for male manufacturing workers

\begin{tabular}{|c|c|c|c|c|c|c|c|c|}
\hline & \multicolumn{4}{|c|}{ Log wages } & \multicolumn{4}{|c|}{ Weekly Hours of work } \\
\hline & \multicolumn{2}{|c|}{$\underline{\mathrm{OLS}}$} & \multicolumn{2}{|c|}{$\underline{\text { Two-step estimator }}$} & \multicolumn{2}{|c|}{$\underline{\mathrm{OLS}}$} & \multicolumn{2}{|c|}{$\underline{\text { Two-step estimator }}$} \\
\hline & (1) & $(2)$ & (3) & (4) & (5) & (6) & (7) & (8) \\
\hline \multirow[t]{2}{*}{$\overline{\mathrm{POST}}$} & $0.103^{* * *}$ & $0.0956 * * *$ & 0.089 & 0.09 & $-0.913 * * *$ & $-0.880 * * *$ & -0.755 & -0.736 \\
\hline & $(0.01)$ & $(0.01)$ & $(0.05)$ & $(0.05)$ & $(0.21)$ & $(0.22)$ & $(0.593)$ & $(0.554)$ \\
\hline \multirow[t]{2}{*}{ Pre-law wage gap } & $-0.263^{* *}$ & $-0.240 * *$ & $-0.242 * *$ & $-0.203^{* *}$ & $2.208 * *$ & $1.670 *$ & $2.461^{* *}$ & $2.013^{*}$ \\
\hline & $(0.08)$ & $(0.09)$ & $(0.09)$ & $(0.08)$ & $(0.95)$ & $(0.82)$ & (1.101) & $(0.957)$ \\
\hline \multirow[t]{2}{*}{ Pre-law wage gap*POST } & 0.042 & 0.042 & 0.002 & 0.003 & $1.366^{* *}$ & $1.208 *$ & 0.795 & 0.744 \\
\hline & $(0.04)$ & $(0.04)$ & $(0.13)$ & $(0.13)$ & $(0.59)$ & $(0.55)$ & $(1.438)$ & $(1.271)$ \\
\hline $\mathrm{N}$ & 3,631 & 3,631 & 18 & 18 & 4,824 & 4,824 & 18 & 18 \\
\hline
\end{tabular}

Robust standard errors presented in each column and all regressions are weighted. Each regresssion contains a constant (coefficient not shown). In columns 1, 2, 5 and 6, standard errors are Eicker-White, clustered at the province level. Significance at $\mathrm{p}<0.001^{* * *}, \mathrm{p}<0.05^{* *}$ or $\mathrm{p}<0.01 *$ level. Critical values for significance of between estimates and for twostep estimates are taken from the t-distribution (9-4=5 degrees of freedom). See text for details. Sample includes all African and coloured male workers of relevant age and education level employed in manufacturing, in all waves excluding the cusp wave September 2002.

POST=1 in March 2003, September 2003 and March 2004; otherwise zero.

Pre-law wage gap is the province-level difference in the log(median wage)-log(4.1), where 4.1 is the urban full-time minimum wage introduced in November 2002 and median wage is the median wage of domestic workers in each province across all of the pre-waves (September 2001 and March 2002). 
Table 6: Testing for partial compliance in response to the law: Marginal effects from ordered probit

\begin{tabular}{|c|c|c|c|c|c|c|}
\hline \multirow{4}{*}{$\begin{array}{l}\text { Average change in predicted probability of } \\
\text { domestic worker reporting nominal wages in the } \\
\text { non-compliant, near-compliant or compliant } \\
\text { region }\end{array}$} & \multicolumn{3}{|c|}{$\underline{\text { Before-After comparison }}$} & \multicolumn{3}{|c|}{ Before-After comparison by intensity of the law } \\
\hline & \multicolumn{2}{|c|}{$\underline{\delta_{1}}=0.9 * \mathrm{w}_{\min }$} & \multirow{2}{*}{$\begin{array}{l}\underline{\delta_{1}=0.8 *} \mathrm{~W}_{\min } \\
\underline{\text { All controls }}\end{array}$} & \multicolumn{2}{|c|}{$\underline{\delta_{1}}=0.9 * \mathrm{w}_{\min }$} & \multirow{3}{*}{$\begin{array}{l}\underline{\delta_{1}=0.8 * \mathrm{w}_{\min }} \\
\underline{\text { All controls }} \\
(6)\end{array}$} \\
\hline & No controls & $\underline{\text { All controls }}$ & & No controls & All controls & \\
\hline & $(1)$ & $(2)$ & $(3)$ & $(4)$ & $(5)$ & \\
\hline \multicolumn{7}{|l|}{ Change in fraction with non-compliant wages } \\
\hline $\begin{array}{l}\operatorname{Pr}\left(\mathrm{w}^{*}=0 \mid \operatorname{POST}\right)-\operatorname{Pr}\left(\mathrm{w}^{*}=0 \mid \mathrm{PRE}\right) \\
\text { Chanae in fraction with near-compliant waaes }\end{array}$ & $\begin{array}{c}-0.149 * * * \\
(0.016)\end{array}$ & $\begin{array}{c}-0.139 * * * \\
(0.016)\end{array}$ & $\begin{array}{c}-0.147 * * * \\
(0.016)\end{array}$ & $\begin{array}{c}-0.141^{* * *} \\
(0.026)\end{array}$ & $\begin{array}{c}-0.134^{* * *} \\
(0.026)\end{array}$ & $\begin{array}{c}-0.141 * * * \\
(0.026)\end{array}$ \\
\hline $\operatorname{Pr}\left(\mathrm{w}^{*}=1 \mid \operatorname{POST}\right)-\operatorname{Pr}\left(\mathrm{w}^{*}=1 \mid \mathrm{PRE}\right)$ & $\begin{array}{c}0.007 * * * \\
(0.001)\end{array}$ & $\begin{array}{c}0.007^{* * * *} \\
(0.001)\end{array}$ & $\begin{array}{c}0.012^{* * *} \\
(0.002)\end{array}$ & $\begin{array}{c}0.008 * * * \\
(0.002)\end{array}$ & $\begin{array}{c}0.008 * * * \\
(0.002)\end{array}$ & $\begin{array}{c}0.010 * * * \\
(0.002)\end{array}$ \\
\hline \multicolumn{7}{|l|}{ Change in fraction with compliant wage } \\
\hline $\operatorname{Pr}\left(\mathrm{w}^{*}=2 \mid \operatorname{POST}\right)-\operatorname{Pr}\left(\mathrm{w}^{*}=2 \mid \mathrm{PRE}\right)$ & $\begin{array}{c}0.142 * * * \\
(0.015)\end{array}$ & $\begin{array}{c}0.132 * * * \\
(0.015)\end{array}$ & $\begin{array}{c}0.138 * * * \\
(0.015)\end{array}$ & $\begin{array}{c}0.133^{* * *} \\
(0.025)\end{array}$ & $\begin{array}{c}0.127 * * * \\
(0.025)\end{array}$ & $\begin{array}{c}0.131 * * * \\
(0.024)\end{array}$ \\
\hline \multicolumn{7}{|l|}{ Change in fraction with non-compliant wages } \\
\hline $\operatorname{Pr}\left(\mathrm{w}^{*}=0 \mid \mathrm{POST} * \mathrm{WG}\right)-\operatorname{Pr}\left(\mathrm{w}^{*}=0 \mid \mathrm{PRE} * \mathrm{WG}\right)$ & & & & $\begin{array}{l}-0.077 \\
(0.051)\end{array}$ & $\begin{array}{c}-0.084^{*} \\
(0.051)\end{array}$ & $\begin{array}{c}-0.085 * \\
(0.050)\end{array}$ \\
\hline \multicolumn{7}{|l|}{ Change in fraction with near-compliant wages } \\
\hline $\operatorname{Pr}\left(\mathrm{w}^{*}=1 \mid \mathrm{POST} * \mathrm{WG}\right)-\operatorname{Pr}\left(\mathrm{w}^{*}=1 \mid \mathrm{PRE} * \mathrm{WG}\right)$ & & & & $\begin{array}{c}0.004 \\
(0.003)\end{array}$ & $\begin{array}{c}0.004 \\
(0.003)\end{array}$ & $\begin{array}{c}0.005 \\
(0.003)\end{array}$ \\
\hline $\begin{array}{l}\text { Change in fraction with compliant wage } \\
\operatorname{Pr}\left(\mathrm{w}^{*}=2 \mid \mathrm{POST} \mathrm{T}^{*} \mathrm{WG}\right)-\operatorname{Pr}\left(\mathrm{w}^{*}=2 \mid \mathrm{PRE}{ }^{*} \mathrm{WG}\right)\end{array}$ & & & & $\begin{array}{c}0.073 \\
(0.048)\end{array}$ & $\begin{array}{l}0.080 * \\
(0.048)\end{array}$ & $\begin{array}{l}0.080 * \\
(0.047)\end{array}$ \\
\hline $\mathrm{N}$ workers & 5,206 & 5,206 & 5,206 & 5,206 & 5,206 & 5,206 \\
\hline \multicolumn{7}{|c|}{$\begin{array}{l}\text { Robust standard errors in parentheses. Significant at } \mathrm{p}<0.001^{* * *}, \mathrm{p}<0.05^{* *} \text { or } \mathrm{p}<0.01^{*} \text { level. All regressions weighted. } \\
\text { Results are predicted changes in the probability of falling into one of three groups generated from an ordered probit model. The three groups are: non-compliant (w=0), near- } \\
\text { compliant }(\mathrm{w}=1) \text { and compliant ( } \mathrm{w}=2 \text { ). The near-compliant group is defined as the set of wages } 10 \% \text { below the minimum or less; } 20 \% \text { below the minimum or less in each of } \\
\text { columns }(1-2) \text { and (3). Marginal effects are calculated using STATA's mfx command, which computes the "effect" of switching a binary variable from } 0 \text { to } 1 . \\
\text { Sample restricted to urban female domestic workers ages } 20-59 \text { in pre- and post-periods (Sep 01-Mar 04), excluding the cusp wave (September } 2002) \text {. } \\
\text { Each specification includes a constant and an indicator for whether the observation is captured PRE or POST law. Columns (2) and (3), (5) and (6) present results from models } \\
\text { which control for age, race, years of education. Columns (4), (5) and (6) present results from the specification that controls for a POST indicator, a measure of the log wage gap in } \\
\text { the province before the law was in effect, and the interaction of POST with wage gap (WG). The estimates in the lower panel of columns (4)-(6) are the coefficients and standard } \\
\text { errors on the interaction of POST*WG. }\end{array}$} \\
\hline
\end{tabular}


Table 7: Wage responses in areas with high versus low costs of complaint: Difference-in-differences

\begin{tabular}{|c|c|c|c|c|c|c|c|c|}
\hline & \multicolumn{4}{|c|}{ All waves } & \multicolumn{4}{|c|}{ Excluding "cusp" wave } \\
\hline & \multicolumn{2}{|c|}{ OLS } & \multicolumn{2}{|c|}{ Two-step estimator } & \multicolumn{2}{|c|}{$\underline{\text { OLS }}$} & \multicolumn{2}{|c|}{ Two-step estimator } \\
\hline & $(1)$ & (2) & (3) & (4) & (5) & (6) & (7) & (8) \\
\hline POST & $\begin{array}{c}0.239 * * * \\
(0.04)\end{array}$ & $\begin{array}{c}0.240^{* * *} \\
(0.04)\end{array}$ & $\begin{array}{l}-0.212 \\
(0.14)\end{array}$ & $\begin{array}{l}-0.198 \\
(0.24)\end{array}$ & $\begin{array}{c}0.258^{* * *} \\
(0.02)\end{array}$ & $\begin{array}{c}0.257 * * * \\
(0.02)\end{array}$ & $\begin{array}{l}-0.155 \\
(0.23)\end{array}$ & $\begin{array}{l}-0.164 \\
(0.23)\end{array}$ \\
\hline Pre-law wage gap (WG) & $\begin{array}{c}-0.964 * * * \\
(0.06)\end{array}$ & $\begin{array}{c}-0.943 * * * \\
(0.08)\end{array}$ & $\begin{array}{c}-0.816^{* *} \\
(0.31)\end{array}$ & $\begin{array}{c}-0.761 * * \\
(0.38)\end{array}$ & $\begin{array}{c}-1.008^{* * *} \\
(0.04)\end{array}$ & $\begin{array}{c}-0.979 * * * \\
(0.06)\end{array}$ & $\begin{array}{l}-0.483 \\
(0.30)\end{array}$ & $\begin{array}{l}-0.422 \\
(0.30)\end{array}$ \\
\hline Pre-law wage gap (WG)*POST & $\begin{array}{l}0.137 \\
(0.10)\end{array}$ & $\begin{array}{l}0.153 \\
(0.09)\end{array}$ & $\begin{array}{l}1.137^{*} \\
(0.46)\end{array}$ & $\begin{array}{l}1.088 \\
(0.65)\end{array}$ & $\begin{array}{c}0.180^{* *} \\
(0.06)\end{array}$ & $\begin{array}{c}0.196 * * * \\
(0.05)\end{array}$ & $\begin{array}{l}0.804 \\
(0.61)\end{array}$ & $\begin{array}{l}0.812 \\
(0.64)\end{array}$ \\
\hline Labor Center & $\begin{array}{c}0.116^{* * *} \\
(0.03)\end{array}$ & $\begin{array}{c}0.114^{* * *} \\
(0.03)\end{array}$ & $\begin{array}{l}-0.184 \\
(0.13)\end{array}$ & $\begin{array}{l}-0.119 \\
(0.22)\end{array}$ & $\begin{array}{c}0.122 * * * \\
(0.02)\end{array}$ & $\begin{array}{c}0.121^{* * *} \\
(0.02)\end{array}$ & $\begin{array}{l}-0.12 \\
(0.20)\end{array}$ & $\begin{array}{l}-0.058 \\
(0.20)\end{array}$ \\
\hline Labor Center*POST & $\begin{array}{l}-0.051 \\
(0.04)\end{array}$ & $\begin{array}{c}-0.0636^{*} \\
(0.03)\end{array}$ & $\begin{array}{l}0.590^{*} \\
(0.18)\end{array}$ & $\begin{array}{l}0.555^{*} \\
(0.33)\end{array}$ & $\begin{array}{c}-0.0568 \\
(0.03)\end{array}$ & $\begin{array}{c}-0.0716^{* *} \\
(0.03)\end{array}$ & $\begin{array}{l}0.527 \\
(0.32)\end{array}$ & $\begin{array}{c}0.52 \\
(0.32)\end{array}$ \\
\hline Labor Center*WG & $\begin{array}{c}0.175^{* *} \\
(0.07)\end{array}$ & $\begin{array}{c}0.201^{* *} \\
(0.07)\end{array}$ & $\begin{array}{l}-0.048 \\
(0.49)\end{array}$ & $\begin{array}{l}-0.077 \\
(0.60)\end{array}$ & $\begin{array}{c}0.175 * * * \\
(0.04)\end{array}$ & $\begin{array}{c}0.193 * * * \\
(0.05)\end{array}$ & $\begin{array}{l}-0.647 \\
(0.48)\end{array}$ & $\begin{array}{l}-0.672 \\
(0.48)\end{array}$ \\
\hline Labor Center*WG*POST & $\begin{array}{l}-0.080 \\
(0.10)\end{array}$ & $\begin{array}{l}-0.094 \\
(0.09)\end{array}$ & $\begin{array}{l}-1.407 \\
(0.70)\end{array}$ & $\begin{array}{l}-1.325 \\
(0.96)\end{array}$ & $\begin{array}{l}-0.079 \\
(0.07)\end{array}$ & $\begin{array}{c}-0.0884 \\
(0.07)\end{array}$ & $\begin{array}{l}-0.807 \\
(0.89)\end{array}$ & $\begin{array}{l}-0.798 \\
(0.93)\end{array}$ \\
\hline $\begin{array}{l}\text { Controls for age, education, } \\
\text { African? }\end{array}$ & $\mathrm{N}$ & $\mathrm{Y}$ & $\mathrm{N}$ & $\mathrm{Y}$ & $\mathrm{N}$ & Y & $\mathrm{N}$ & Y \\
\hline$\overline{\mathrm{N}}$ & 6,154 & 6,154 & 36 & 36 & 5,205 & 5,205 & 36 & 36 \\
\hline
\end{tabular}

Robust standard errors presented in each column and all regressions are weighted. Each regression contains a constant (coefficient not shown). In columns 1, 2, 5 and 6, standard errors are Eicker-White, clustered at the province level. Significance at $\mathrm{p}<0.001^{* * *}, \mathrm{p}<0.05^{* *}$ or $\mathrm{p}<0.01^{*}$ level. Critical values for significance for two-step estimates are taken from the tdistribution (9-8=1 degree of freedom). See text for details. Sample in columns 1-4 include domestic workers in all waves; sample in columns 5-8 exclude domestic workers in the Outcome is the log of hourly wages. Labor Center=1 if the domestic workers in a magisterial district that contains at least one Labor Center (LC) for employee complaints.

POST=1 in March 2003, September 2003 and March 2004; otherwise zero.

Pre-law wage gap is the province-level difference in the log(median wage)-log(4.1), where 4.1 is the urban full-time minimum wage introduced in November 2002 and median wage is the median wage of domestic workers in each province across all of the pre-waves (September 2001 and March 2002). 
Table 8: Contract coverage for domestic workers: Difference-in-differences

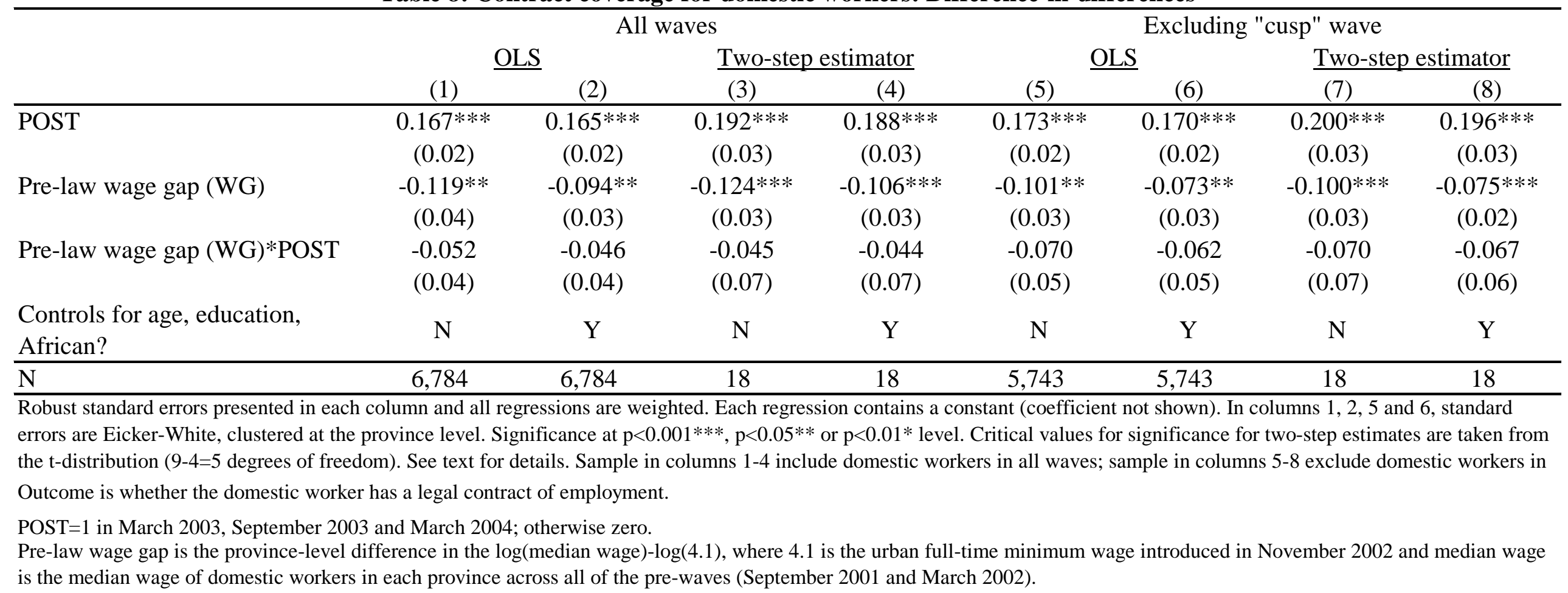




\section{Appendix 1: Testing for evidence of incomplete wage adjustment}

Consider the figure below which shows the wage distribution $\mathrm{F}($.$) of domestic worker wages in the$ period before and after the law. $F_{\text {After }}$ is shifted to the right of $F_{\text {Before }}$ and the solid black vertical line at $\delta_{2}$ represents the minimum wage level. Define $\delta_{1}$ as $90 \%$ of the minimum wage. Then, classify all worker wages into one of three groups: wages below $\delta_{1}$ are non-compliant, wages between $\delta_{1}$ and $\delta_{2}$ are nearly compliant, and wages at or above $\delta_{2}$ are compliant.

We would like to know whether the shift in the wage distribution in response to the law is consistent with incomplete adjustment up to compliant levels. That is, are wages shifting up out of the bottom part of the distribution, but not enough to get most workers up to or over the minimum threshold? Some shifts in the distribution are consistent with this idea and some are not. In example 1 below, the first set of changes in the fraction of workers in each region would be consistent with complete adjustment for some workers up to compliance: $10 \%$ of workers in each of the non-compliant and near-compliant regions leave these regions; and $20 \%$ of workers join the compliant region. The second example is, however, not consistent with full compliance for workers who experience wage changes: $20 \%$ of workers leave the non-compliant region, and the near-compliant region grows by $10 \%$ of workers as does the compliant region. While we cannot say which exact workers are getting wage increase, as long as jobs are not being lost as a result of the law change, then such shifts in the overall distribution reflect partial adjustments in response to the law.

\begin{tabular}{|l|c|c|c|}
\hline & \multicolumn{3}{|c|}{ Example 1 } \\
\hline & Non-compliant region & Near compliant & Compliant \\
\hline Before & 0.3 & 0.3 & 0.4 \\
After & 0.2 & 0.2 & 0.6 \\
\hline
\end{tabular}

\begin{tabular}{|l|c|c|c|}
\hline & \multicolumn{3}{|c|}{ Example 2 } \\
\hline & Non-compliant region & Near compliant & Compliant \\
\hline Before & 0.3 & 0.3 & 0.4 \\
After & 0.1 & 0.4 & 0.5 \\
\hline
\end{tabular}

Intuitively, we would like to know whether or not the fall in the fraction of domestic workers in the non-compliant region is fully offset by the increase in fraction of workers in the compliant region. We do this by implementing an ordered probit model and testing a specific hypothesis. To describe the appropriate hypothesis, consider the following linear model of the $\log$ of the individual worker's wage $\left(w_{i}\right)$ (ignoring covariates for now) where $\epsilon_{i} \sim N(0,1)$ :

$w_{i}=\beta_{0}+t \beta_{1}+\epsilon_{i}$, where $t=1$ if the worker is observed in the after period and $t=0$ if observed in the before period. We define an ordered categorical variable, $w_{i}^{*}$ that captures the region that each wage falls into:

$$
w_{i}^{*}=0 \quad \text { if } \quad w_{i} \leq \delta_{1}
$$




\section{A test for partial compliance}

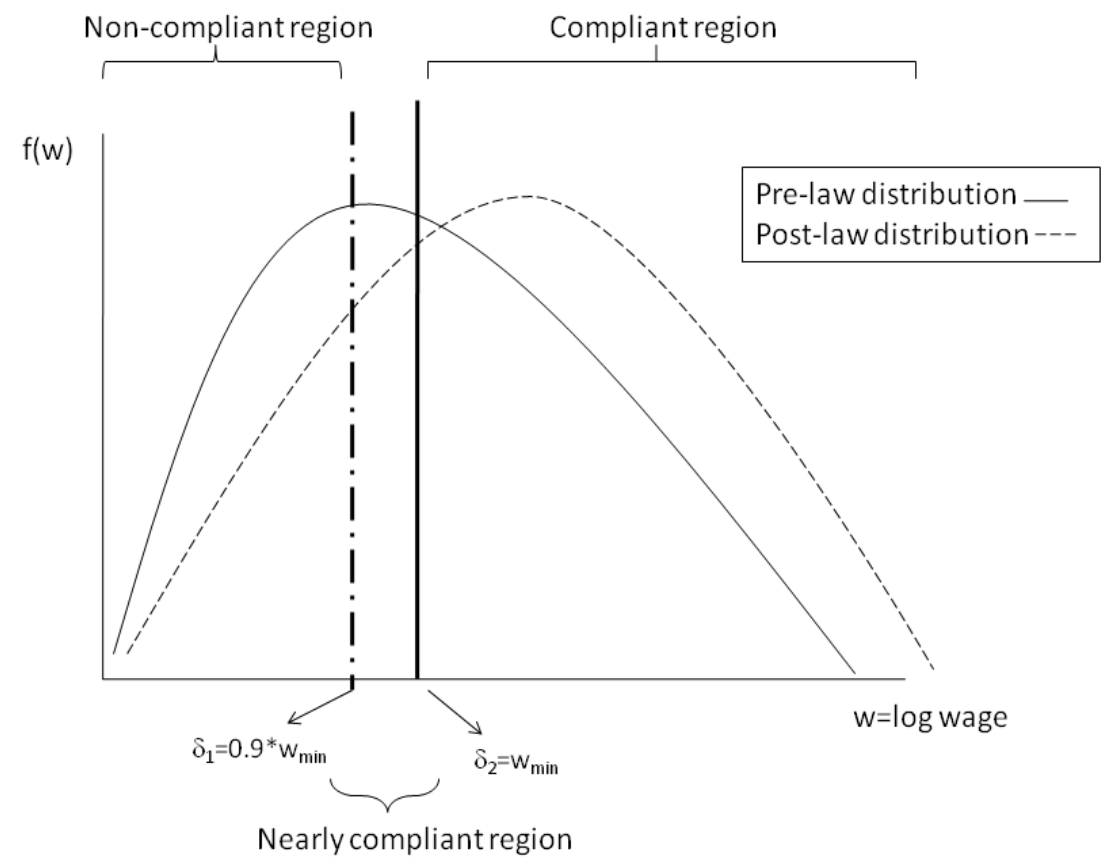

$$
\begin{array}{ccc}
w_{i}^{*}=1 & \text { if } & \delta_{1}<w_{i} \leq \delta_{2} \\
w_{i}^{*}=2 & \text { if } & w_{i}>\delta_{2}
\end{array}
$$

Then, the probability that any worker's wage falls into a particular bin can be described as:

$$
\begin{gathered}
\operatorname{Pr}\left(w_{i}^{*}=0\right)=\operatorname{Pr}\left(w_{i} \leq \delta_{1}\right)=\operatorname{Pr}\left(\beta_{0}+t \beta_{1}+\epsilon_{i} \leq \delta_{1}\right)=\Phi\left(\delta_{1}-\beta_{0}-t \beta_{1}\right) \\
\operatorname{Pr}\left(w_{i}^{*}=1\right)=\operatorname{Pr}\left(\delta_{1}<\beta_{0}+t \beta_{1}+\epsilon_{i} \leq \delta_{2}\right)=\Phi\left(\delta_{2}-\beta_{0}-t \beta_{1}\right)-\Phi\left(\delta_{1}-\beta_{0}-t \beta_{1}\right) \\
\operatorname{Pr}\left(w_{i}^{*}=2\right)=\operatorname{Pr}\left(\beta_{0}+t \beta_{1}+\epsilon_{i} \geq \delta_{2}\right)=1-\operatorname{Pr}\left(\beta_{0}+t \beta_{1}+\epsilon_{i} \leq \delta_{2}\right)=1-\Phi\left(\delta_{2}-\beta_{0}-t \beta_{1}\right)
\end{gathered}
$$

The hypothesis we would like to test is the following:

$$
H_{0}: \quad \frac{\partial \operatorname{Pr}\left(w_{i}^{*}=2\right)}{\partial t}+\frac{\partial \operatorname{Pr}\left(w_{i}^{*}=0\right)}{\partial t} \geq 0
$$




$$
H_{A}: \quad \frac{\partial \operatorname{Pr}\left(w_{i}^{*}=2\right)}{\partial t}+\frac{\partial \operatorname{Pr}\left(w_{i}^{*}=0\right)}{\partial t}<0
$$

Let the parameter combination described in the hypothesis statement be $\gamma$. If we reject $\gamma \geq 0$, this provides evidence consistent with some domestic workers getting wage increases that are up to a level less than the minimum, i.e. up to a new but still non-compliant level in region $\delta_{2}-\delta_{1}$.

Implementing this test is straightforward. To see this, note that we can write each of the partial derivatives in this way:

$$
\begin{gathered}
\frac{\partial \operatorname{Pr}\left(w_{i}^{*}=2\right)}{\partial t}=\beta_{1} \phi\left(\delta_{2}-\beta_{0}-t \beta_{1}\right) \\
\frac{\partial \operatorname{Pr}\left(w_{i}^{*}=0\right)}{\partial t}=-\beta_{1} \phi\left(\delta_{1}-\beta_{0}-t \beta_{1}\right)
\end{gathered}
$$

This allows us to redefine $\gamma$ as:

$$
\gamma=\frac{\partial \operatorname{Pr}\left(w_{i}^{*}=2\right)}{\partial t}+\frac{\partial \operatorname{Pr}\left(w_{i}^{*}=0\right)}{\partial t}=\beta_{1}\left[\phi\left(\delta_{2}-\beta_{0}-t \beta_{1}\right)-\phi\left(\delta_{1}-\beta_{0}-t \beta_{1}\right)\right]
$$

Finally, note that:

$$
\frac{\partial \operatorname{Pr}\left(w_{i}^{*}=1\right)}{\partial t}=-\beta_{1}\left[\phi\left(\delta_{2}-\beta_{0}-t \beta_{1}\right)-\phi\left(\delta_{1}-\beta_{0}-t \beta_{1}\right)\right]=-\gamma
$$

We use this last partial derivative to re-state the null and alternative hypotheses:

$$
\begin{array}{ll}
H_{0}: & -\gamma \leq 0 \\
H_{A}: & -\gamma>0
\end{array}
$$

In words, we want to know whether the probability of being in the near compliant region rose in the after period, relative to before the law was in place.

We can also extend the test to a framework that includes a measure of the intensity of the law. Suppose that wages are given by $w_{i}=\beta_{0}+t \beta_{1}+W G_{j} \beta_{2}+W G_{j} t \beta_{3}+\epsilon_{i}$, where $W G_{j}$ is the median wage gap for domestic workers in the local labor market during the period before the law. This implies that we can write the partial derivative with respect to $t$ as:

$$
\frac{\partial \operatorname{Pr}\left(w_{i}^{*}=1\right)}{\partial t}=\left(-\beta_{1}-W G_{j} t \beta_{3}\right)\left[\phi\left(\delta_{2}-\beta_{0}-t \beta_{1}\right)-\phi\left(\delta_{1}-\beta_{0}-t \beta_{1}\right)\right]
$$

Our test will involve examining the signs and significance of the marginal effect of $t$, at the mean level of the pre-law wage gap. 


\section{Appendix 2 Figure 1: Shift in observable characteristics of urban domestic workers}

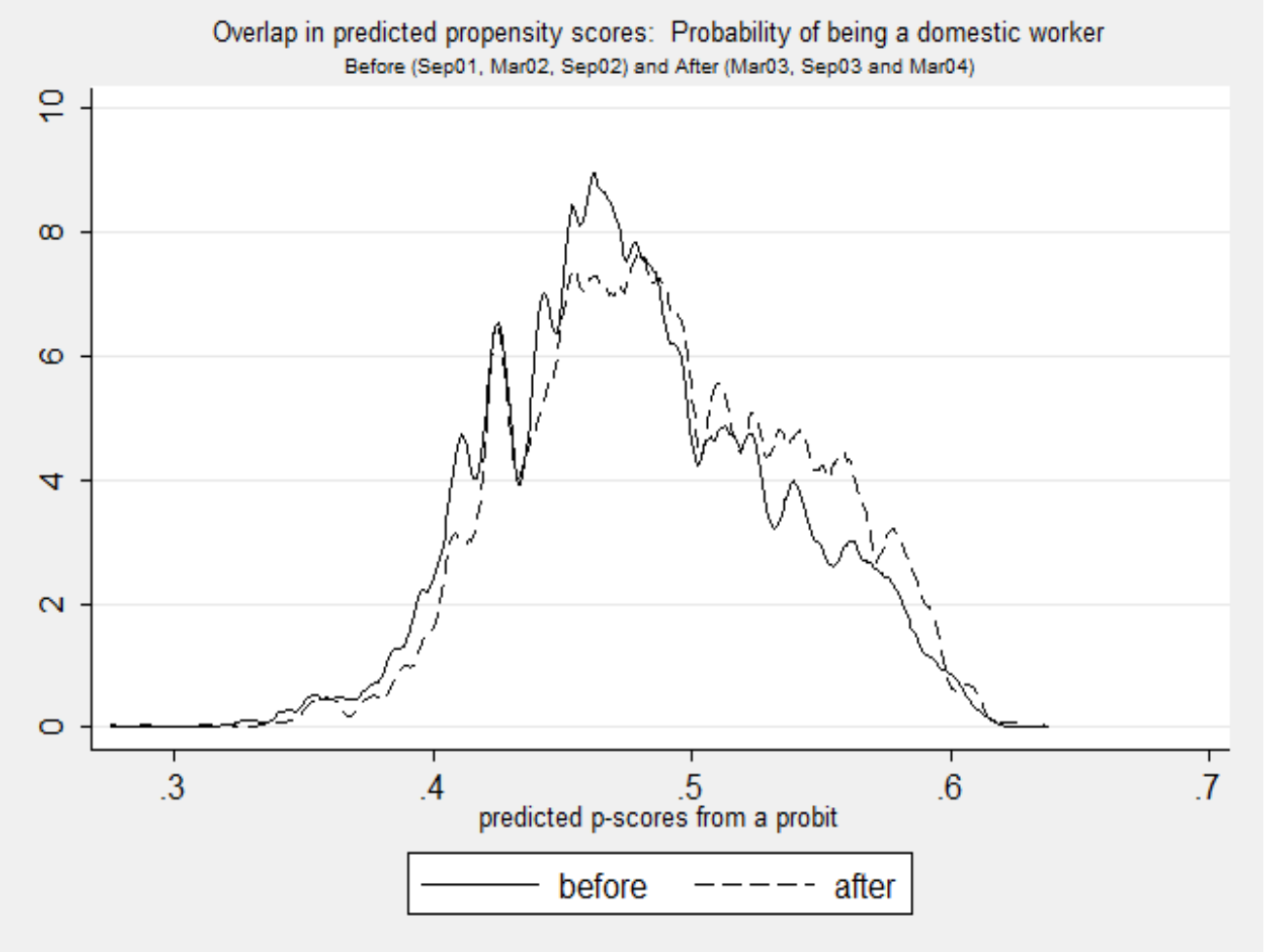

Kernel density plot of predicted propensity scores from a probit of whether the individual is observed in the pre- or $P O S T$ periods. The probit regression includes controls for age, age-squared, an African indicator, years of education, nine province dummies and the sample used in the regression is restricted to all domestic workers in urban areas who appear in five LFS waves from September 2001 to March 2004. All density estimates use an Epanechnikov kernel and a bandwidth selector one-quarter the size of Stata's 'optimal' bandwidth which is the width that minimizes the mean integrated squared error if the data were Gaussian and a Gaussian kernel were used. Sample sizes for the pre- and POST periods are 3,947 and 3,349 respectively. 


\section{Appendix 2 Figure 2: Wage distributions reweighted for $\Delta$ in observable characteristics}

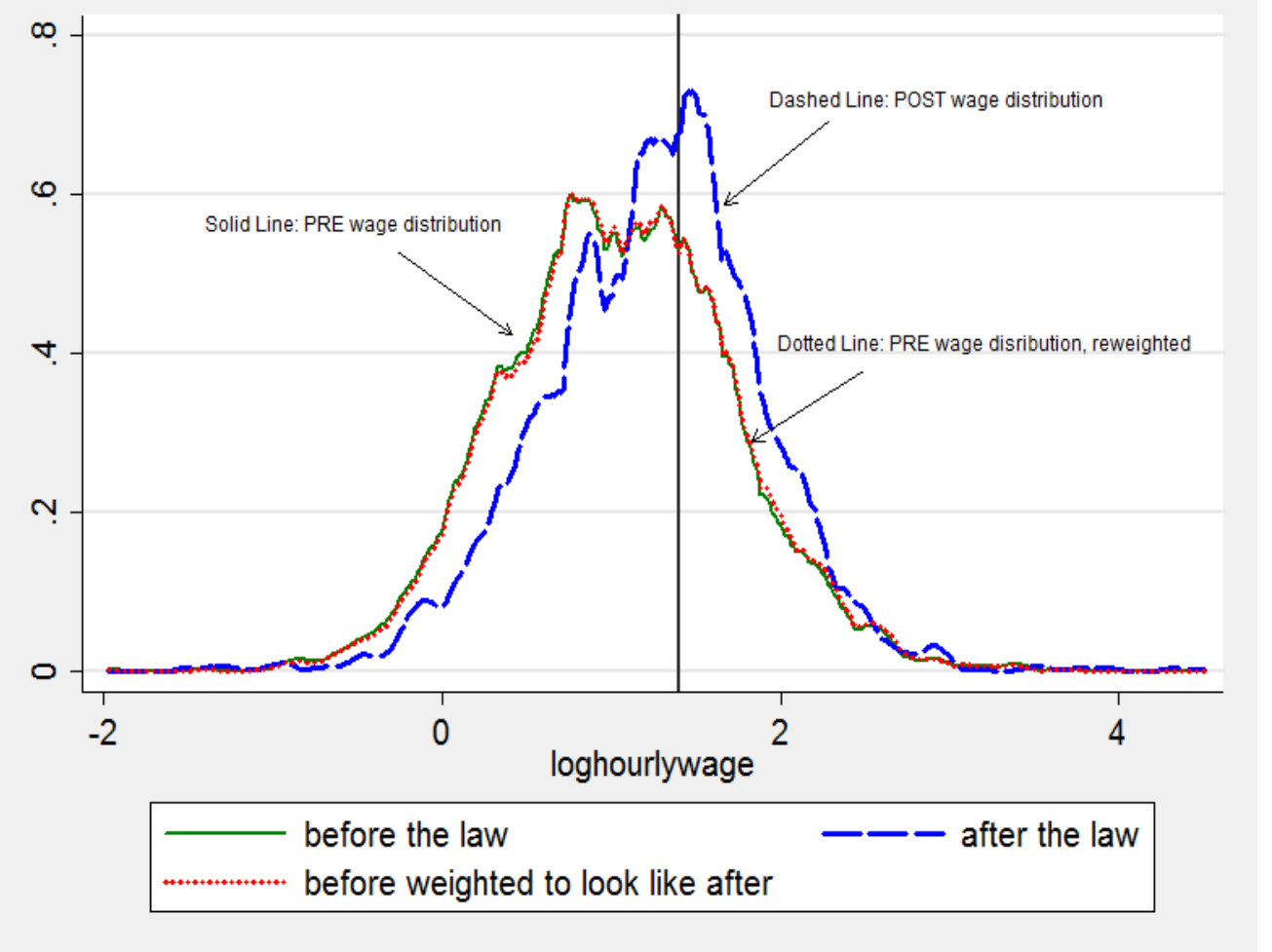

Kernel density graph of log real wage distributions for domestic workers pre- and post-law. The figure shows wage distributions in the pre-period, in the post-period, and in the pre-period re-weighted to force the distribution of observable characteristics in the pre-period to look like the distribution in the post-period (i.e. adjusting for the change in the distribution of observables: age, age-squared, African, years of education and province). All density estimates use an Epanechnikov kernel and a bandwidth selector one-half the size of Stata's 'optimal' bandwidth which is the width that minimizes the mean integrated squared error if the data were Gaussian and a Gaussian kernel were used. Sample sizes for the pre- and POST periods are 3,947 and 3,349 respectively. 
Appendix 3 Table 1: Log hourly wages of domestic workers: Difference-in-differences, unweighted

\begin{tabular}{|c|c|c|c|c|c|c|c|c|}
\hline & \multicolumn{4}{|c|}{ All waves } & \multicolumn{4}{|c|}{ Excluding "cusp" wave } \\
\hline & \multicolumn{2}{|c|}{$\underline{\mathrm{OLS}}$} & \multicolumn{2}{|c|}{$\underline{\text { Two-step estimator }}$} & \multicolumn{2}{|c|}{$\underline{\mathrm{OLS}}$} & \multicolumn{2}{|c|}{$\underline{\text { Two-step estimator }}$} \\
\hline & (1) & $(2)$ & (3) & (4) & (5) & $(6)$ & (7) & (8) \\
\hline POST & $\begin{array}{l}0.198^{* * *} \\
(0.01)\end{array}$ & $\begin{array}{l}0.188^{* * *} \\
(0.01)\end{array}$ & $\begin{array}{c}0.194 * * * \\
(0.03)\end{array}$ & $\begin{array}{l}0.183^{* * *} \\
(0.03)\end{array}$ & $\begin{array}{c}0.209^{* * *} \\
(0.01)\end{array}$ & $\begin{array}{c}0.197^{* * *} \\
(0.01)\end{array}$ & $\begin{array}{l}0.209 * * * \\
(0.03)\end{array}$ & $\begin{array}{l}0.197^{* * *} \\
(0.03)\end{array}$ \\
\hline Pre-law wage gap (WG) & $\begin{array}{c}-0.829 * * * \\
(0.05)\end{array}$ & $\begin{array}{c}-0.808 * * * \\
(0.05)\end{array}$ & $\begin{array}{c}-0.808^{* * *} \\
(0.05)\end{array}$ & $\begin{array}{c}-0.787 * * * \\
(0.04)\end{array}$ & $\begin{array}{c}-0.874 * * * \\
(0.05)\end{array}$ & $\begin{array}{c}-0.850 * * * \\
(0.05)\end{array}$ & $\begin{array}{c}-0.848 * * * \\
(0.04)\end{array}$ & $\begin{array}{c}-0.822 * * * \\
(0.04)\end{array}$ \\
\hline Pre-law wage gap (WG)*POST & $\begin{array}{c}0.109 * * * \\
(0.03)\end{array}$ & $\begin{array}{c}0.111^{* * *} \\
(0.03)\end{array}$ & $\begin{array}{l}0.102 \\
(0.07)\end{array}$ & $\begin{array}{c}0.103^{*} \\
(0.06)\end{array}$ & $\begin{array}{c}0.154^{* * *} \\
(0.03)\end{array}$ & $\begin{array}{c}0.157^{* * *} \\
(0.03)\end{array}$ & $\begin{array}{c}0.142^{* *} \\
(0.06)\end{array}$ & $\begin{array}{c}0.147^{* *} \\
(0.06)\end{array}$ \\
\hline $\begin{array}{l}\text { Controls for age, education, } \\
\text { African? }\end{array}$ & $\mathrm{N}$ & $\mathrm{Y}$ & $\mathrm{N}$ & $\mathrm{Y}$ & $\mathrm{N}$ & Y & $\mathrm{N}$ & $\mathrm{N}$ \\
\hline $\mathrm{N}$ & 6,154 & 6,154 & 18 & 18 & 5,205 & 5,205 & 18 & 18 \\
\hline
\end{tabular}

Robust standard errors presented in each column. In columns 1, 2, 5 and 6, standard errors are Eicker-White, clustered at the province level. Significance at $\mathrm{p}<0.001^{* * *}$, $\mathrm{p}<0.05^{* *}$ or $\mathrm{p}<0.01 *$ level. Critical values for significance for two-step estimates are taken from the t-distribution (9-4=5 degrees of freedom). See text for details. Sample in columns $1-4$ include domestic workers in all waves; sample in columns 5-8 exclude domestic workers in the September 2002 "cusp" wave.

Outcome is the log of hourly wages, computed by taking monthly earnings and dividing by usual number of hours worked per week.

POST $=1$ in March 2003, September 2003 and March 2004; otherwise zero.

Pre-law wage gap is the province-level difference in the $\log ($ median wage)-log(4.1), where 4.1 is the urban full-time minimum wage introduced in November 2002 and median wage is the median wage of domestic workers in each province across all of the pre-waves (September 2001 and March 2002). 
Appendix 3 Table 2: Usual weekly hours of work of domestic workers: Difference-in-differences, unweighted

\begin{tabular}{|c|c|c|c|c|c|c|c|c|}
\hline & \multicolumn{4}{|c|}{ All waves } & \multicolumn{4}{|c|}{ Excluding "cusp" wave } \\
\hline & \multicolumn{2}{|c|}{$\underline{\text { OLS }}$} & \multicolumn{2}{|c|}{$\underline{\text { Two-step estimator }}$} & \multicolumn{2}{|c|}{$\underline{\text { OLS }}$} & \multicolumn{2}{|c|}{ Two-step estimator } \\
\hline & $(1)$ & $(2)$ & $(3)$ & (4) & (5) & (6) & $(7)$ & $(8)$ \\
\hline \multirow[t]{2}{*}{ POST } & -0.512 & -0.446 & -0.557 & -0.471 & -0.798 & -0.664 & -0.622 & -0.516 \\
\hline & $(0.62)$ & $(0.59)$ & $(1.73)$ & $(1.54)$ & $(0.88)$ & $(0.82)$ & $(1.75)$ & $(1.54)$ \\
\hline \multirow[t]{2}{*}{ Pre-law wage gap (WG) } & 5.208 & 4.084 & $5.990 * *$ & $5.219 *$ & 5.641 & 4.426 & $6.810^{* *}$ & $5.910 * *$ \\
\hline & $(3.03)$ & $(2.46)$ & $(2.76)$ & $(2.44)$ & $(3.52)$ & $(2.77)$ & $(3.06)$ & $(2.66)$ \\
\hline $\begin{array}{l}\text { Controls for age, education, } \\
\text { African? }\end{array}$ & $\mathrm{N}$ & $\mathrm{Y}$ & $\mathrm{N}$ & Y & $\mathrm{N}$ & Y & $\mathrm{N}$ & $\mathrm{Y}$ \\
\hline $\mathrm{N}$ & 6,876 & 6,876 & 18 & 18 & 5,824 & 5,824 & 18 & 18 \\
\hline
\end{tabular}

Robust standard errors presented in each column. In columns 1, 2, 5 and 6, standard errors are Eicker-White, clustered at the province level. Significance at p<0.001***, $\mathrm{p}<0.05^{* *}$ or $\mathrm{p}<0.01^{*}$ level. Critical values for significance for two-step estimates are taken from the t-distribution (9-4=5 degrees of freedom). See text for details. Sample in columns 1-4 include domestic workers in all waves; sample in columns 5-8 exclude domestic workers in the September 2002 "cusp" wave.

Outcome is usual number of hours worked per week.

POST=1 in March 2003, September 2003 and March 2004; otherwise zero.

Pre-law wage gap is the province-level difference in the log(median wage)-log(4.1), where 4.1 is the urban full-time minimum wage introduced in November 2002 and median wage is the median wage of domestic workers in each province across all of the pre-waves (September 2001 and March 2002 ). 